\title{
El Concilio Provincial de Tarragona de 1564/65
}

José Goñi Gaztambide

\section{Introducción}

Esta modesta aportación pretende esclarecer en lo posible la historia del concilio provincial de Tarragona de 1564/65, el más desconocido de los siete concilios provinciales celebrados en España a raíz del Concilio de Trento ${ }^{1}$. En ella se publican por vez primera unas cuantas piezas inéditas -cartas, decretos, actas, - conservadas en el Archivo General de Simancas, cuya reproducción en microfilm se nos facilitó gentilmente, por lo que nos apresuramos a expresar nuestro más vivo agradecimiento. Ellas despejan algunas incógnitas, no todas, y permiten seguir día a día el desarrollo del concilio, sobre todo en su primera fase.

${ }^{1}$ Las actas de los concilios de Toledo, Valencia, Compostela (Salamanca), Zaragoza y Granada, en JUAN TEJADA Y RAMIRO, Colección de cánones y de todos los concilios de la Iglesia de España y de América (Madrid 1855) tomo V. Más completas en la edición de 1859-1863, tomos V y VI. - Bibliografia: A. MARÍN OCETE, El concilio provincial de Granada en 1565, en: Archivo Teológico Granadino 25 (1962) 23-178; I. PÉREZ DE HEREDIA, Concilio Provincial de Granada de 1565: edición crítica, en: Anthologica Annua 37 (1990) 381-842; J.L.SANTOS DíEZ, Política conciliar postridentina en España. El Concilio Provincial de Toledo de 1565, Ibid., 15 (1967) 309-461 (hay tirada aparte, Roma 1969, 159 págs.); IDEM, Los concilios particulares postridentinos, en la obra colectiva El concilio de Braga y la función de la legislación particular en la Iglesia (Salamanca 1975) 185-211; E. RODRf́GUEZ AMAYA, El concilio provincial de Salamanca de 1565 y sus repercusiones en Plasencia, en: Revista de Estudios Extremeños 8 (1951) 235-295; J.L. GoNZÁlez NovALín. Ventura y desgracia de don Fernando de Valdés, Arzobispo de Sevilla. Un episodio tridentino y el concilio provincial hispalense, en: Anthologica Annua 11 (1963) 91-126; J. GOÑI GAZTAMBIDE, El concilio provincial de Zaragoza de 1565 (en preparación); IDEM, Historia de los obispos de Pamplona, IV (Pamplona 1985) 73-80 (sobre el mismo concilio). 


\section{El metropolitano y sus sufragáneos}

El primer dato nuevo y seguro que aporta la documentación de Simancas es la fecha de apertura, dos de octubre de 1564, que hace del concilio de Tarragona el primero cronológicamente de la serie española. En aquel momento estaba al frente de la provincia eclesiástica de Cataluña Fernando de Loazes y contaba como sufragáneos a los obispos de Gerona, Arias Gallego; de Lérida, Antonio Agustín; de Barcelona, Guillermo Cassador; de Tortosa, Martín de Córdoba; de Seo de Urgel, Pedro de Castellet, y de Vich, Benito de Tocco, recién nombrado (6 septiembre 1564).

Fernando de Loazes (c. 1498-1568), nacido en Orihuela, era doctor en ambos Derechos, formado en la Universidad de Pavía y con toda probabilidad también en la Universidad de Bolonia. Por el año 1522 fue nombrado abogado y promotor fiscal del tribunal inquisitorial de Valencia, y como tal publicó un opúsculo titulado Perutilis et singularis quaestio seu tractatus super nova paganorum regni Valentiae conversione (1525), dedicado al inquisidor general Alonso de Manrique, arzobispo de Sevilla. Se hallaba al comienzo de su brillante carrera y naturalmente anhelaba ascender. De ahí que no ahorrara incienso al inquisidor general.

De hecho, a partir de 1530 fue nombrado inquisidor de Barcelona; en 1542, obispo de Elña; en 1543, visitador de Cataluña, el Rosellón y la Cerdaña; en el mismo año, obispo de Lérida, asistiendo en calidad de tal a la segunda etapa del Concilio de Trento (1551-1552) después de haber celebrado dos sínodos diocesanos (1545 y 1550). En 1553 fue trasladado a la sede de Tortosa, de donde pasó a la metropolitana de Tarragona (26 abril 1560). En atención a su cargo de visitador real, Pío IV le autorizó a residir en Barcelona. En 1566 Pío V le confirió el cargo honorífico de patriarca de Antioquía y al año siguiente lo promovió a la sede arzobispal de Valencia, donde falleció no mucho después (28 febrero 1568). Varios escritos, unos impresos y otros manuscritos, han perpetuado su memoria ${ }^{2}$.

2 G. GUTIÉRREZ, Españoles en Trento (Valladolid 1951) 342-331; IDEM, Trento, un concilio para la unión (Madrid 1981) I 654; II 373 y 474; IDEM, Trento, un problema: la última convocatoria del Concilio, 1552-1562. I. Estudio (Madrid 1995) 367; J. LÓPEZ MAYMÓN, Biografía de don Fernando de Loazes (Murcia 1922); J. GoÑI GAZTAMBIDE, La polémica sobre el bautismo de los 
Arias Gallego (c. 1500-1575), de origen seguramente extremeño, licenciado en ambos Derechos, desempeñó el oficio de inquisidor de la fe en Aragón a mediados del siglo XVI. Con el título de obispo de Gerona, que recibió en 1556, asistió a la tercera convocatoria del Concilio de Trento, interviniendo piadosa y doctamente unas veces y otras con valentía rayana en la temeridad. Vuelto a su sede, participó activamente en la primera fase del concilio provincial de Tarragona. Las relaciones con su cabildo catedralicio fueron en ocasiones difíciles. En 1565 fue presentado para la diócesis de Cartagena, donde celebró ocho sínodos diocesanos consecutivos, falleciendo en Murcia el 28 de abril de $1575^{3}$.

Antonio Agustín (1517-1586) fue una figura excepcional. Canonista y jurista, humanista y teólogo, arqueólogo, numísmata, heraldista y epigrafista. Natural de Zaragoza, cursó Humanidades en su ciudad natal, dos años de Artes en Alcalá (1526-1528) y siete de leyes en Salamanca (1528-1534), facultad la más deficiente. En 1536 pasó a Bolonia, donde tuvo por maestro al célebre jurista Andrés Alciati. En 1539 ingresó en el colegio de San Clemente de Bolonia, doctorándose en derecho (1541). Dos años después comenzó sus publicaciones, que causaron sensación en Europa. Paulo III lo llamó a Roma como auditor de la Rota (1544). Los papas lo emplearon en misiones diplomáticas (1555 en el Imperio y en Inglaterra, 1558 en Viena). Felipe II lo nombró visitador de Sicilia (1559).

Entre tanto fue promovido a los obispados de Alife (Nápoles) (1557), Lérida (1560) con la orden de dirigirse a Trento, donde fue uno de los prelados más eminentes, y Tarragona (1576), donde murió el 31

moriscos a principios del siglo XVI en: Evangelización y teología en América. X Simposio Internacional de Teología, I (Pamplona 1990) 95-203; E. OLMOS Y CANALDA, Los prelados valentinos (Madrid 1949) 179-181.

${ }^{3}$ GuTiÉRREZ, Españoles en Trento, 148-151; G. VAN GULIK - C. EUBEL, Hierarchia catholica, III (Münster 1923), $2^{\text {a }}$ ed., 202 y 154; J. VILlanUEVA, Viage literario a las iglesias de España, 14 (Madrid 1826) 86-88; España Sagrada. 44, 112-115; J.P. TEJERA, Biblioteca del Murciano, II (Madrid 1941) 84; MARTín PÉREZ DE AYALA, Discurso de su vida, cap. XX; PEDRO GONZÁLEZ DE MENDOZA, Memoria de lo sucedido en el Concilio de Trento (Buenos Aires 1947) $2^{a}$ ed., p.143 (Colección Austral). La obra fue editada en Concilium Tridentinum. Diariorum, de la Sociedad Görresiana (Friburgo 1904) II 635-719. 
de mayo de 1586. Como obispo de Lérida promulgó el Tridentino (1564), asistió al concilio provincial de Tarragona en sus dos fases y celebró sínodo diocesano (31 diciembre 1564), en medio de las protestas de los canónigos, que consideraban atropellados sus privilegios ${ }^{4}$.

Guillermo Cassador (c. 1505-1570), catalán, probablemente natural de Vich, doctor en ambos Derechos, fue arcediano de San Fructuoso de Tarragona (1546-1549) y abad de San Félix de Gerona (1546-1560), canónigo de Barcelona y canciller en el Consejo de Aragón. El 29 de junio de 1560 fue nombrado coadjutor con derecho a sucesión de su tío el octogenario Jaime Cassador, obispo de Barcelona, sucediéndole medio año más tarde. Intervino con frecuencia en los debates del Concilio de Trento en su fase final (1562-1565). Asistió al concilio provincial de Tarragona de 1564-1565 y también a otro concilio provincial tarraconense celebrado en Barcelona bajo su presidencia en 1569 en nombre del metropolitano. Expiró en Barcelona el 14 de noviembre de $1570^{5}$.

Fray Martín de Córdoba, OP. (1512-1581), natural de Córdoba, hijo ilegítimo del Conde de Cabra, Diego Fernández de Córdoba, ingresó en la Orden de Predicadores en el convento de San Pablo de su ciudad natal, donde estudió Artes y comenzó la Teología. Previamente había cursado Humanidades y se aficionó a la Música, afición que conservó toda su vida, llegando a ser un brillante cantor y un hábil organista. Ganó por oposición una beca en el Colegio Mayor dominicano de Sevilla, ingresando en el colegio el 11 de noviembre de 1533 . Terminados sus estudios, se dedicó sucesivamente a la docencia y al gobierno de conventos, llegando a ser provincial de Andalucía. Siempre se distinguió por su observancia regular.

Promovido al obispado de Tortosa (17 julio 1560), en Trento, por rivalidad hacia el Arzobispo de Granada, Pedro Guerrero, que no podía competir con él en nobleza y a quien por eso no podía soportar como jefe del grupo episcopal español, adoptó con frecuencia una postura curialista. A su regreso del Concilio, acudió a la asamblea provincial

${ }^{4}$ GUTIÉRREZ, Españoles en Trento, 92-125; IDEM, Diccionario de Historia ecl. de España I (Madrid 1972) 16-17; IDEM, Trento, un problema, 43, 88-96, $119,167,355,361,477,493,499,500,504$ y 572; V. BELTRÁN DE HEREDIA, Cartulario de la Universidad de Salamanca, III (Salamanca 1971) 551-563; C. FLORES SELLÉS, Epistolario de Antonio Agustín (Salamanca 1980); España Sagrada, 47, 93-103; VILlANUEVA, Viage, 17, 58-73 y 272-276.

5 Españoles en Trento, 546-549; EUBEL, III 129. 
tarraconense y visitó varias veces su diócesis. Ascendió después a las sillas de Plasẹncia (1574) y Córdoba (1578). Aquí murió el 5 de junio de $1581^{6}$.

Pedro de Castellet, presbítero de la diócesis de Tarragona, fue instituido obispo de Urgel el 8 de agosto de 1561. De familia noble, era canónigo y sacrista de Tarragona. Como síndico de su cabildo, asistió a algunos concilios provinciales desde 1543. Como obispo de Urgel intervino en los concilios de 1564/65 y de 1569. En 1566 presidió un sínodo diocesano que promulgó los decretos tridentinos. Murió en Barcelona el 1 de febrero de $1571^{7}$.

Fray Benito de Tocco, nacido en Nápoles en 1514 de noble cuna, sirvió de copero a Carlos V; pero cansado de la vida cortesana, se retiró a una ermita cerca del monasterio de Montserrat, hasta que el 21 noviembre 1542 tomó el hábito benedictino en dicho cenobio, trocando el nombre de Marco Antonio por el de Benito. Desempeñó dos veces el cargo de abad de Montserrat (1556-59 y 1562-64). A presentación de Felipe II, ascendió al obispado de Vich (6 septiembre 1564), tomando posesión el 31 de octubre del mismo año. Entiéndase posesión personal, no por procurador, ya que tres días antes estaba actuando en el concilio tarraconense. En Vich se ocupó de asuntos locales. Trasladado a Gerona (5 septiembre 1572), conservó la paz con la ciudad y con el cabildo, pese a ciertas dificultades. Apoyó la construcción de la catedral y celebró sínodo diocesano. Fue transferido a Lérida (11 mayo 1583), «pero desde 1581 se hallaba en el monasterio de Montserrat, cuya visita se le había encargado por comisión apostólica. No debió venir a su iglesia, pues murió en aquella casa a 31 de enero de 1585. En ella se le dio sepulturas ${ }^{8}$.

6 Españoles en Trento, 744-751; D.I. GÓNGORA, Historia del Colegio Mayor de Sevilla (Sevilla 1890) II 86-89; J.GóMEZ BRAvo, Catálogo de los obispos de Córdoba (Córdoba 1778) II 506-522; A, FERNÁNDEZ, Historia y anales de la ciudad y obispado de Plasencia (Madrid 1627) 242-252; G. GONZÁleZ DÁvilA, Teatro eclesiástico de las las iglesias... de las dos Castillas (Madrid 1645-1700) 4 vols., II 505.

7 VillanueVa, Viage, 11, 448-449; EuBEL, III 324.

${ }^{8}$ ES 44122 (ob. Gerona); ES 47104 (ob. Lérida); G. ARGAIZ, La perla de Cataluña (Madrid 1677) cap. 52; EUBEL III 332, 202 y 212; DHEE III 1604; E. ZARAGOZA PASCUAL, Monjes profesos de Montserrat, en: Studia Monastica 33 (1991) 338; J.L. MONCADA, Episcopologio de Vich II (Vich 1894) 503-510. 
López Martínez de Lagunilla, clérigo de la diócesis de Albarracín, seguramente de Teruel, licenciado en ambos Derechos, inquisidor en Cataluña, a presentación de Felipe II fue promovido al obispado de Elna (20 julio 1558). Asistió a la tercera etapa del Concilio de Trento. Después tomó parte en las dos fases del concilio tarraconense y celebró dos sínodos diocesanos, falleciendo el 15 de diciembre de $1567^{9}$.

\section{Representaciones diocesanas}

En el concilio provincial de Tarragona estuvieron también representados los monasterios, las colegiatas y las catedrales, En nombre de los monasterios participaron sus abades, priores o procuradores, y por los cabildos, sus síndicos.

Juan de Tormo, abad de San Pedro de Besalú, OSB, diócesis de Elna.

Pedro de Frigola, abad de San Benito de Bages, OSB, (Gerona).

Miguel Sarrano, abad de S. Vicente de Cardona, de canónigos regulares (Urgel).

Jerónimo Contiioch, abad de Santas Creus, OCist. (Tarragona).

Ludovido de Cervilión, abad de San Cugat del Vallés, OSB (Barcelona).

Cosme Damián de Hortolá, abad de Villabertrán, de canónigos regulares de San Agustín (Gerona) ${ }^{10}$.

Tomás Costa, abad comendatario de San Saturnino de Tabérnoles (Urgel).

Miguel de Agulló, abad comendatario de San Lorenzo de Bagano, OSB (Urgel).

Pablo Plá, abad comendatario de San Pedro de Galligans (Gerona).

Miguel Ferrer, prior del monasterio de San Jaime de Calaf, de la orden de canónigos regulares de San Agustín (Vich).

Geraldo Vilana, prior del monasterio de Santa María de Campo, de la Orden de canónigos regulares de San Agustín, diócesis de Elna.

Juan de Funes, prior del monasterio de San Vicente de Roda, de la Orden de canónigos regulares de San Agustín, diócesis de Lérida.

Rafael Juan Gili, canónigo y síndico del cabildo tarraconense.

Pedro Pablo Zaragoza, canónigo y síndico del cabildo catedral de Barcelona. 
Francisco de Castelvell, canónigo y síndico del cabildo leridano,

Jaime Cerveró, arcediano de Corbera, canónigo y síndico de la iglesia de Tortosa.

Pedro Traver, canónigo y síndico del cabido gerundense.

Pedro Spin, arcediano mayor, canónigo y síndico del cabildo catedral de Urgel.

Miguel Domenec, canónigo y síndico del cabildo de la iglesia de Vich.

Miguel de Homs, abad comendatario del monasterio de Arlés, canónigo, sacrista y síndico del cabildo de Elna.

Martín de Marquina, monje y procurador de Pedro Boqués, abad del monasterio de Santa María de Poblet, cisterciense (Tarragona).

Francisco de Tordelaguna, monje y procurador de Benito de Tocco, abad del monasterio de Montserrat, diócesis de Vich.

Lorenzo Ysalguer, canónigo y procurador de Miguel de Agullana, abad comendatario del monasterio de San Juan de las Abadesas, de canónigos regulares de San Agustín (Vich).

Jaime Moragues, canónigo del monasterio de Santa Ana de Barcelona, procurador de Carlos de Cardona, abad comendatario del monasterio de Santa María del Stany, de la Orden de San Agustín, administrador del referido monasterio de Santa Ana.

Fray Gisbert de Malars, monje y camerario de Santa María de Ripoll, procurador de Bernardo Capeller, abad comendatario del monasterio de Santa María de Serrateix OSB (Urgel).

Juan Guzmán, monje, síndico y procurador de la comunidad de San Victorián, OSB (Lérida), sede abacial vacante.

Raimundo Sopena, monje, síndico y procurador del monasterio de la $\mathrm{O}, \mathrm{OSB}$ (Lérida) abadía vacante ${ }^{11}$.

Los religiosos de las Ordenes Mendicantes, al parecer, no fueron invitados al concilio.

\section{Estado de los monasterios y de los cabildos}

Al parecer, las diócesis catalanas estaban supersaturadas de monasterios y de cabildos de canónigos regulares de la Orden de San Agustín. Su estado moral y disciplinar dejaba bastante que desear. Comencemos por las monjas. 
El 1 de febrero de 1548 Paulo III facultó al arzobispo de Sevilla Fernando de Valdés y al de Valencia, Santo Tomás de Villanueva para reformar por una sola vez los monasterios de monjas, incluso exentos, en Cataluña, el Rosellón y la Cerdaña ${ }^{12}$. Si llegaron a ejecutar la comisión, no debió de resultar muy fructífera. Como veremos más adelante, fuera de algunos conventos de clarisas y de dominicas, en los demás (benedictinas, cistercienses, agustinas y sanjuanistas) no se guardaba la clausura ni querían obligarse a ella ni se consideraban comprendidas en los decretos tridentinos. Si el Concilio dispone que se restablezca la clausura donde estuviere quebrantada, las monjas referidas dicen que eso no va con ellas. No se las puede obligar a un género de vida que ellas no han profesado ${ }^{13}$.

No lo entendía así el obispo de Lérida, Antonio Agustín, que había tomado parte en la elaboración de los decretos tridentinos. En su edicto sobre la clausura de las monjas afirma que, de el dejar de castigar los delitos, nace la frecuencia de los mismos. Tal repetición provoca la ira de Dios que ha castigado a los contemporáneos con epidemias, herejías, guerras y persecuciones. Para aplacar la ira divina debemos practicar obras contrarias a las pasadas. «Y de ninguna cosa vemos que tanto se ofenda Dios y que menos se castigue, que es el abominable pecado de sacrilegio, incesto, estupro y adulterio, que algunos de cierto tiempo a esta parte han cometido con infamia de casas de religión y deshonra de las personas de ellas, que por personas infernales han sido sacadas de su antigua limpieza y de su sancta institución, regla y orden». El Concilio de Trento ha encargado a los obispos que restauren y conserven la clausura de las monjas de cualquier calidad o condición que sean, y el Papa Pío IV les ha mandado que guarden y hagan guardar en toda su diócesis los decretos tridentinos.

Por eso ordena «a todas y cualesquiera abadesas, prioras, comendadoras o monjas profesas de cualquier regla, orden o establecimiento que sean, que se hallen fuera de la clausura de sus monasterios o casas de religión..., que dentro de seis días... vuelvan a sus monasterios o casas ya dichas so pena de excomunión latae sententiae». $\mathrm{Y}$ a las que están dentro, que no salgan de la clausura sin licencia escrita del obispo. Si alguno osare entrar dentro de la clausura sin previa licencia escrita del

12 GUTIÉRREZ, Trento, un problema, 363.

13 Apéndice, $\mathrm{n}^{\circ} .17$. 
prelado diocesano, incurrirá en excomunión ipso facto sin otra monición. Con las mujeres y niños menores de siete años se muestra más benévolo. No así con los estudiantes mayores de catorce años ni con los clérigos y seglares que frecuenten los monasterios ni con los que cometiesen algún sacrilegio dentro o fuera del monasterio. Si no basta la excomunión, se agravarán las censuras y se procederá a la captura y a otras penas arbitrarias conforme a la cualidad de las personas y de los delitos (13 septiembre 1564$)^{14}$.

Este edicto, publicado unos días antes de la apertura del concilio provincial de Tarragona, produce una penosa impresión sobre el estado de los monasterios femeninos en la diócesis ilerdense.

No era mejor la situación de los eclesiásticos a juzgar por algunas fuentes. El obispo de Gerona, Juan de Margarit, quedó autorizado por el Papa para castigar hasta con la degradación a los clérigos exentos y no exentos de Cataluña, el Rosellón y la Cerdaña (18 marzo 1551) ${ }^{15}$. En la diócesis de Urgel, según el cardenal de la curia el mallorquin Jaime Púteo (Pou o Pozzo), clerici sunt multum licentiosi et pretextu exentionum multa enormia committunt (8 diciembre 1552) ${ }^{16}$.

Sobre el monasterio de Santa María del Stany, diócesis de Vich de canónigos regulares de San Agustín, y sobre el priorato de Santa Ana de Barcelona, de Canónigos del Santo Sepulcro, consignó el cardenal Púteo: examinavi testes de mala vita istorum monachorum (1 abril 1548) ${ }^{17}$. El decreto del concilio provincial de Tarragona del 6 de noviembre de 1564 pone de manifiesto que los monjes negros y las religiosas de San Benito llevaban una vida laxa con pocas ganas de enmienda ${ }^{18}$. Si hemos de creer a Cosme Damián de Hortolá, abad del monasterio de Santa María de Villabertrán, sus canónigos vivían perdidamente y eludían la reforma con apelaciones urdidas con calumnias y mentiras (13 febrero 1566) ${ }^{19}$.

Sin embargo, no todo era corrupción. El abad de Villabertrán ardía en deseos de reformar a sus súbditos y sin duda no era el único en Cataluña. En el Memoriale dubiorum, del que vamos a tratar enseguida,

14 VillanueVA, Viage 17, 276-278; apéndice de dicho tomo, $\mathrm{n}^{\circ}$.XXVI.

15 GUTIÉRREZ, Trento, un problema, 364-365.

16 Ibid., 17.

17 Ibidem.

18 Apéndice, $\mathrm{n}^{\circ} .12$.

19 TEJADA VI 127-238. 
las personas eclesiásticas y seculares muestran deseos de poder servir a Dios con quietud espiritual y corporal, y observar los decretos tridentinos del mejor modo que les sea posible ${ }^{20}$. En la carta del concilio al Rey, los Padres aseguran que por gracia de Dios hay en la provincia de Tarragona «grande celo de cristiandad» ${ }^{21}$. La asistencia masiva de abades y procuradores al concilio provincial puede interpretarse como un signo alentador.

«El agravamiento de la clausura en los monasterios femeninos, necesario a causa de su relajación disciplinar, obstaculizó el compromiso de la mujer en las tareas educativas y sociales, de las que Angela de Merici había ofrecido un espléndido ejemplo. Antes del concilio vivían con igual derecho monasterios cerrados y monasterios abiertos, entonces no sometidos a la ley de la clausura. Su reforma en Trento, como la de todos los regulares, se puso sobre el tapete sólo en los últimos días cuando todos tenían prisa por partir. De ahí que los decretos no pudieran menos de resentirse de ello: 'son bastante superficiales' escrbió Calini. El problema de los monasterios abiertos fue expresamente descartado. De ahí las dudas posconciliares sobre su posición jurídica, que Pío V resolvió drásticamente (1566) haciendo obligatoria la clausura para todas las comunidades de votos solemnes, aun cuando alardeasen de indultos contrarios. Era cerrar a la mujer consagrada el acceso al apostolado. Con el tiempo la Santa Sede se mostró menos rígida en su aplicación» ${ }^{22}$.

El Dr. H. Jedin puntualiza: «También quedó marginado el problema institucional, la existencia de monasterios abiertos que vivían bajo la regla de la orden tercera y actuaban caritativamente ${ }^{23}$. Con regla o sin regla, la mujer continuó trabajando en los hospitales y en la enseñanza de las niñas.

20 Ibid. 121.

21 Ibid., 123.

${ }^{22}$ M. SCADUTO, Conspectus bibliographici. 2. Concilio di Trento e Riforma Cattolica, en: Archivum Historicum Societatis Iesu 38 (1969) 504-505 (resumen de un trabajo de R. CEYSENS, La riforma dei monasteri femminili dopo i decreti tridentini).

${ }^{23}$ H. JEDIN, Historia del Concilio de Trento, IV/II (Pamplona 1981) 265. 


\section{LA FASE TARRACONENSE (1564)}

\section{Choque con el Patronato Real}

El concilio se desarrolló en dos fases: una en Tarragona y otra en Barcelona. La primera duró algo más de un mes ( 2 octubre a 7 noviembre 1564); la segunda, unos cuatro meses en 1565 , pero se desconoce la fecha exacta de su comienzo y de su fin.

El 12 de octubre de 1564 Fernando de Loazes, metropolitano de Tarragona, escribió tres cartas a Felipe $\mathrm{II}^{24}$. En la primera le comunicaba que estando en visita pastoral, había convocado el concilio de su provincia para el día dos del mismo mes con el fin de aceptar los decretos tridentinos. En el momento en que le escribía, estaban reunidos en Tarragona, todos los obispos, abades, priores y cabildos del principado de Cataluña. Se esforzará para que todas las decisiones se adopten por unanimidad, como conviene al sosiego de esta tierra, que está sobre esto no poco conmovida y alterada. No se consentirá nada contra la real corona.

La segunda era más extensa. Motivo: se ha comenzado a tratar de nombrar personas que examinen si son hábiles los candidatos episcopales, elegidos por el rey. Parece que quieren ponerle sobrestantes. Él se opone. No se puede abordar este tema sin previo conocimiento del monarca. Casi todos asienten y escriben al soberano. El papa suele examinar a los presentados para las mitras. Por eso le parece innecesario poner examinadores.

Los partidarios de la elección de examinadores se basaban en el capítulo I del decreto De reformatione de la sesión XXIV del Concilio de Trento (11 noviembre 1563), que establece el procedimiento a seguir en la creación de obispos y cardenales. Respecto de la creación de obispos, el Concilio hace hincapié en que se promuevan buenos pastores, capaces de gobernar la iglesia, que sean nacidos de legítimo matrimonio, de buena conducta, edad, doctrina y demás cualidades exigidas por los sagrados cánones y los decretos tridentinos.

Para tomar informes sobre todas las circunstancias mencionadas, «manda el santo Concilio, que en el sínodo provincial que debe celebrar el metropolitano, se prescriba en cualesquiera lugares y provincias el método peculiar de hacer el examen o averiguación o información que 
pareciere ser más útil y conveniente a los mismos lugares, el mismo que ha de ser aprobado a arbitrio del santísimo Pontífice Romano ${ }^{25}$. Los padres estaban en su derecho al plantearse un tema que el concilio de Trento había reservado a los concilios provinciales. Loazes no tenía motivo para sospechar maliciosamente que, al hacerlo, miraban exclusivamente a quitar al rey el patronato que poseía por haber recuperado el territorio español de los moros.

La tercera carta es obra común del arzobispo y del concilio. Le plantean el asunto de los examinadores y le piden una respuesta urgente. Entre tanto el concilio estará en suspenso, si bien continuó trabajando sin tregua hasta el 6 de noviembre inclusive.

\section{Un Concilio improvisado}

De las anteriores cartas se desprende claramente que el concilio de Tarragona fue un concilio improvisado. Cuando los padres se reunieron el 2 de octubre de 1564, se encontraron sin un programa de trabajo y sin un proyecto de Constituciones Provinciales, ya preparado. En principio los cabildos, los abades sin jurisdicción plena y los procuradores sólo poseían voto consultivo. En el concilio tarraconense los asuntos se decidian por consenso. Todos los votos tenían igual valor. A los obispos que no estaban conformes con las resoluciones adoptadas, no les quedaba otro recurso que votar en contra. El metropolitano perdió la dirección y se limitó a contentar a la mayoría y a echar la culpa a otros.

\section{Recepción del Concilio de Trento}

Mientras llegaba la respuesta del rey, el concilio realizó el acto más importante: la aceptación oficial en bloque del Concilio de Trento ( 24 octubre 1564). La solemne ceremonia se desarrolló en la capilla del sacratísimo Cuerpo de Cristo del claustro de la catedral de Tarragona. En ella se juntaron a concilio el metropolitano, los obispos, abades, priores y otros prelados, los síndicos y procuradores, en presencia de Damián Gili, notario público y escribano del concilio, y de varios testigos. Siguiendo lo dispuesto en el capítulo II del Decreto $D e$

25 Conciliorum oecumenicorum decreta, $3^{\mathrm{a}}$ ed. (Bologna 1973) 760; El sacrosanto y ecumenico Concilio de Trento, traducido al idioma castellano por don Ignacio López de Ayala. Agrégase el texto latino corregido según la edición auténtica de Roma, publicada en 1564 (Madrid 1787), $3^{\mathrm{a}}$ ed. , 314. 
reformatione del concilio tridentino, que comienza Cogit temporum calamitas, todos unánimes y conformes aceptaron públicamente todos y cada uno de los decretos del concilio de Trento y prometieron obediencia al papa Pío IV y a sus sucesores, detestaron y anatematizaron todas las herejías $\mathrm{y}$ ordenaron al referido notario que levantara acta del acontecimiento, como así lo hizo. El texto, en la parte esencial, había sido publicado por Tejada, con la omisión de las firmas de los asistentes, que ya conocemos ${ }^{26}$. Se trata de un documento larguísimo, cuya elaboración supone varias horas y quizá días de intenso trabajo.

\section{El memoriale dubiorum}

Al mismo tiempo los padres habían emprendido el estudio de las dificultades y dudas que suscitaban algunos decretos tridentinos. Es un tema que atrajo la atención casi exclusiva del concilio durante sus dos fases sucesivas. Si hemos de creer a Tejada, después de la aceptación en bloque del Concilio de Trento, se procedió a la lectura del Memoriale dubiorum circa nonnulla decreta Concilii Tridentini lectum in Concilio Tarraconensi 1564 die 24 octobris mittendum domino Papae, compuesto por Pedro Pablo Zaragoza, Jaime Moragues y fray Gisbert de Molars $^{27}$. Quizá se trate de un estado embrionario del Memorial, sobre todo en los dos últimos puntos, que todavía no se habían estudiado a fondo. Por otra parte, varias de las ideas que en él se apuntan, no reaparecen en los decretos publicados en las últimas congregaciones. $\mathrm{He}$ aquí su contenido.

La observancia de varios decretos tridentinos, relativos al derecho positivo y a la reforma de las costumbres, les parece demasiado difícil y no poco perjudicial al estado eclesiástico de la provincia de Tarragona. Por eso suplican al papa que, informado de su situación, régimen, aspereza y otras cualidades de dicha provincia, de la multitud de sus beneficios y de la tenuidad de sus rentas, de la pobreza de muchos monasterios y del modo cómo sus comunidades han solido vivir hasta el presente, como pastor óptimo, fiel dispensador y padre benignísimo, se digne remediar las necesidades de esta provincia y de las personas eclesiásticas tanto seculares como regulares, a fin de que, superadas las dificultades, puedan servir a Dios con quietud espiritual y corporal, 
observar del mejor modo que puedan los decretos del Santo Concilio y obedecer al Santísimo Pontífice.

El primer artículo se refiere a la residencia de los canónigos y dignidades. Al parecer, los que hoy poseen una canonjía, prebenda $\mathrm{o}$ dignidad de la catedral juntamente con una parroquial, no están obligados a residir en la parroquia. En cambio han sido revocadas las dispensas relativas a la posesión simultánea de una canonjía con dos parroquiales.

A su juicio, los canónigos deben residir con preferencia en la catedral, porque la iglesia madre es más digna y porque los canónigos son los consejeros de los obispos. Y pueden disfrutar de una doble porción, porque en toda Cataluña no se encuentra prebenda alguna que supere el valor de cien ducados. De ahí que, para su congruo sustento necesiten de rentas parroquiales. Por tanto hay que suplicar al papa que, puesto que esta dispensa de prebenda con una parroquial única no ha sido revocada, en esta provincia se deje en manos de los obispos que provean que los canónigos titulares de una parroquia, residan en ella durante cierto tiempo del año según la calidad de las iglesias.

Una sola cosa en esta provincia parece excusar de la residencia a todos los rectores indistintamente, cuando viven en lugares montañosos $\mathrm{y}$ agrestes, $\mathrm{y}$ sometidos de tal manera a hombres facinerosos que apenas pueden habitar seguros allí. En el espacio de dos años en Cataluña han sido asesinados más de 40 sacerdotes por facinerosos. Otros muchísimos han sido azotados, robados y despojados de todos sus bienes. Más todavía, muchos han sido atormentados para que manifestasen dónde guardaban el dinero. Nada de esto aparece en la documentación de Simancas.

El segundo artículo sólo ocupa dos líneas: Sobre mantener las dispensas. Pedir que no se quiten las dispensas de tener varias iglesias a la vez, sobre todo a las personas nobles.

Sobre la pluralidad de beneficios

De los monjes negros, cistercienses, canónigos regulares y monjas. Piden que las dificultades que exponen sobre la vida común, etc., se consulten al papa.

\section{Decretos del concilio tarraconense}

Tres días después (27 octubre 1564) el rey firmó las respuestas al arzobispo y al concilio de Tarragona, pero no llegaron a su destino hasta 
el 7 de noviembre, y entre tanto los padres continuaron profundizando en los temas que se acaban de indicar. El 28 de octubre la asamblea, reunida en el palacio arzobispal, se ocupó de la consulta que pedían las monjas, cuyo tema no se expresa. A petición de las religiosas el concilio acuerda elevar al papa una consulta, sin pretender innovar, interpretar ni mudar lo más mínimo los decretos tridentinos ni apartarse de su ejecución. Se encomendó la redacción a los obispos de Barcelona y de Vich, a los abades de Besalú, Poblet y Galligans y al prior de Santa María de Campo. El texto se leería ante los padres antes de su expedición. Votaron en contra los obispos de Lérida y Elna ${ }^{28}$.

El 30 de octubre se publicó un decreto sobre la residencia de los inferiores, que consistía en que se consultase al papa sobre la residencia de los inferiores en los beneficios con cura de almas. Si un canónigo, dignidad o racionero, titular de una parroquia, cumplía residiendo en la catedral o en la colegiata. Votaron en contra los obispos de Gerona, Lérida y Tortosa y el abad de Villabertrán. Para ellos la consulta era innecesaria, puesto que los decretos tridentinos estaban claros y no admitían duda. Sus votos se han conservado íntegros ${ }^{29}$.

El 31 de octubre el concilio provincial publicó otro decreto para que se consultase al papa sobre algunas dudas en torno a dispensas de beneficios curados que en apariencia no habían quedado revocadas por el concilio tridentino. Los cuatro disidentes votaron en contra ${ }^{30}$.

En el mismo día el concilio, pese a los cuatro votos contrarios de costumbre, estima indispensable consultar al Romano Pontífice cuántos beneficios simples podría recibir un canónigo juntamente con un beneficio curado, dada la tenuidad de las rentas canonicales, y hasta qué suma se podrían considerar tenues las rentas ${ }^{31}$.

El 2 de noviembre, decreto sobre la resignación de beneficios. Muchos titulares de varios beneficios curados resignaron todos sus beneficios, menos uno, de acuerdo con el Concilio de Trento, en manos del papa, reservándose una pensión. Pero, por la brevedad del tiempo

28 Apéndice $n^{\circ} .7$.

29 El decreto y los votos contrarios en el Apéndice $n^{\circ}$. 8. Hemos ordenado cronológicamente los decretos tarraconenses, que en la copia de Simancas están algún tanto revueltos.

\footnotetext{
${ }^{30}$ Apéndice $n^{\circ} .9$.

${ }^{31}$ Apéndice $\mathrm{n}^{\circ} .10$.
} 
muchísimos se enteraron tarde de que el plazo de seis meses señalado por el tridentino para la resigna, comenzó a correr el 1 de mayo de 1564. Por eso, para no incurrir en las penas previstas, se vieron obligados a renunciar sus beneficios en manos de los ordinarios. El concilio provincial pide al papa se digne reservar una pensión en favor de los resignantes como si hubieran renunciado en manos del sumo pontífice $^{32}$.

El último decreto, fechado el 6 de noviembre, se refiere a los monjes negros y a las benedictinas. Desde tiempo inmemorial llevaban una vida laxa: peculio, comida de dos en dos o de tres en tres en sus. celdas, etc. Pretenden no estar obligados a un modo de vida estricto, pero dudan si su género de vida se ajusta a los decretos tridentinos. Algo parecido sucede con las religiosas, cuyos monasterios son pobrísimos, pero piensan que no se les puede imponer una vida común que no han profesado. Sobre todo ello el concilio cree oportuno recurrir al papa. Por otra parte, algunos monasterios, por culpa de los comendatarios se hallaban arruinados en sus edificios, dormitorios, refectorio y otras oficinas, sin recursos para repararlos, y muchos oficios claustrales, comenzando por el de abad, en manos de clérigos seculares. El concilio pide al papa remedie esta situación, devuelva los oficios a los religiosos de los mismos monasterios y en adelante se abstenga de conceder nuevas encomiendas $^{33}$.

Según Tejada, en el mismo día, en virtud del decreto tridentino de la sesión XXV cap. 2 De reformatione, se mandó a Lope Martínez de Lagunilla, obispo de Elna, no sometido a metropolitano alguno, que eligiera a quién quería obedecer. El interesado optó por el metropolitano tarraconense, con lo que fue admitido y gozó de los privilegios de esta provincia y de sus Constituciones ${ }^{34}$. Como lo hemos visto intervenir antes, habrá que anticipar la fecha de su admisión, a no ser que supongamos una admisión de hecho y otra de derecho.

\section{Suspensión del concilio}

Con una rapidez inusual, Felipe II contestó a las cartas del 12 de octubre. La respuesta se recibió el 7 de noviembre causando la mayor

32 Apéndice $\mathrm{n}^{\circ} .11$.

33 Apéndice $n^{\circ} .12$.

34 TEJADA VI 120. 
decepción ${ }^{35}$. El rey desaprobaba la reunión del concilio. Tenían que haberle consultado antes, si la celebración era procedente. Él había concebido su plan, que consistía en celebrar simultáneamente todos los concilios provinciales de sus reinos «cuando y como yo lo mandaré avisar, que será presto». Entretanto debe suspenderse ese concilio hasta después de Pascua de Resurrección. El arzobispo procederá con el mayor disimulo como cosa suya. El monarca se considera jefe indiscutuble de la Iglesia española. El virrey de Cataluña les explicará con detalle su pensamiento. No responde al problema que le plantearon sobre el nombramiento de examinadores. Quizá esta cuestión cogió desprevenida a la corte ${ }^{36}$. Les agradece que le hayan consultado, pero «hubiéramos holgado... que el juntarse y el comenzar a tratar destos negocios fuera en tiempo que se hiciera lo mismo en ese y en los otros mis reinos y no antes, porque procediendo todos unánimes y con buena inteligencia y conformidad de todas las partes, se pudiera mejor poner en execución lo que el sacro Concilio de Trento dispone y manda, que es lo que queremos, pretendemos y deseamos, como sabéis y lo escribimos más particularmente a vos el arzobispo» (27 oct. 1564).

Requeséns fue, al parecer, el inspirador de la celebración simultánea de los concilios. En carta del 22 de febrero de 1564 había escrito al rey desde Roma: «Como otras veces he escrito a V.M. pienso que conviene que los concilios provinciales de España se hagan en un mismo tiempo y que se entiendan los unos con los otros, de manera que todos se conformen, porque estando diferentes, se dará ocasión y abrirá la puerta a que aquí lo declaren como les pareciere o como les conviniere» ${ }^{37}$.

35 Apéndice $\mathrm{n}^{\circ} .5$ (al arz.) y $\mathrm{n}^{\circ} .6$ (al concilio).

36 Unos meses más tarde la corte lanzó una interpretación restrictiva, aplazando indefinidamente su ejecución. El concilio provincial no tiene que ocuparse de las cualidades, ya que están especificadas en los cánones antiguos $\mathrm{y}$ en el Concilio de Trento. Ni tampoco de las personas que han de practicar las instrucciones, que, según el Concilio Tridentino, deben ser el nuncio o el diocesano del obispo promovido. Entrometerse a seffalar persona sería contra lo dispuesto en el Concilio de Trento y en perjuicio del patronato de su Majestad. «Y así tan solamente se ha de tratar y ordenar la forma de las probanzas y averiguaciones que se han de hacer $\mathrm{y}$, porque conviene mucho que esto sea uniforme en todas las provincias de estos reinos, se ha de mirar la orden que se ha de tener para que no difieran los unos de los otros» (MARÍn,132).

37 J.J.IGN.VON DÖLLINGER, Beiträge zur politischen, kirchlichen und Culturgeschichte der sechs letzten Jahrhunderte, I (Regensburg 1862) 552. 
El arzobispo de Santiago Gaspar Zúñiga y Avellaneda no compartía la tesis oficial de celebrar todos los concilios a la vez. Es imposible que entre ellos haya conformidad y correspondencia por la distancia de los lugares, los diferentes usos y costumbres de las provincias, haber menos sufragáneos en unas provincias que en otras (dos en Granada, un montón en Santiago de Compostela). Y por eso se podrían concluir unos concilios antes que otros. Si se celebran en tiempos diferentes, el primero podría dar luz a los siguientes en las cosas comunes ${ }^{38}$.

El arzobispo recibió las cartas el 7 de noviembre por la mañana. La dirigida al concilio fue leída públicamente. Al instante el metropolitano, por sí mismo, suspendió el concilio provincial hasta quince días después de Pascua, es decir, hasta el 7 de mayo de 1565, reservándose el derecho de anticipar las sesiones o de cambiar de lugar donde y cuando le pareciere, para que el rey entendiese que se juntarían siempre que fuere servido y dejarían de reunirse, si en ello fuese deservido, «de modo que la suspensión y prorrogación está hecha de manera que su Majestad puede disponer lo que más servido fuere». Esto se llama servilismo o adulación, postura tanto más llamativa cuanto mayor motivo tenía para estar disgustado. Porque el rey lo había desautorizado sin el menor miramiento, de suerte que el pobre arzobispo se sintió obligado a justificarse en carta a su amigo Gonzalo Pérez, secretario de Estado, por cuyas manos pasaban todos los asuntos de los concilios.

Convocó el concilio contra su voluntad, aunque no pudo menos de convocarlo por dos razones: Primera, porque vio que el rey había aceptado el Concilio de Trento a bombo y platillo, "y con tanta furia, con diversos pregones y atabales y trompetas se había mandado, no sólo a sus súbditos, pero a todos los prelados, que todos hiciesen lo mismo». Segunda, porque vio que entre los obispos, cabildos y otros eclesiásticos reinaba gran discordia y temía un gran escándalo en Cataluña, donde tal vez se pensaba que los decretos tridentinos podrían repercutir negativamente en sus intereses personales.

Le pareció superfluo avisar al rey de ello, viendo lo que les había mandado, es decir, que aceptasen y ejecutasen todas las disposiciones tridentinas. Una de ellas, la relativa a la celebración trienal de concilios provinciales, ordenaba la convocación del primero dentro de un año a 
contar de la terminación del Concilio de Trento, que se clausuró el 4 de diciembre de 1563 .

El metropolitano se cree inocente. Si hay culpa, la tienen los que asesoraron mal al monarca. Antes de admitir el Concilio de Trento, debían haber mirado muy bien en qué cosas le perjudicaba, o al menos antes de mandar que todos sus reinos lo aceptasen y que todos sus súbditos lo cumpliesen.

Por medio del virrey de Cataluña, Felipe II le escribió y mandó que por la vía que mejor le pareciese, «con toda disimulación», prorrogase, esto es, aplazase el concilio provincial. «Estoy admirado cómo no me lo mandó en la primera letra que me envió con mi criado», porque en esta materia de concilios provinciales el arzobispo tiene tan gran poder, «que a sola su voluntad, sin parescer y sin aprobación del concilio, immo ipso contradicente, puede extinguirlo y prorrogarlo, y si en este día yo no hobiera venido a la congregación, hobiera del todo expirado, ansí que si su Majestad por la otra me lo mandara, fuera luego hecho». El arzobispo ha procedido de su propio movimiento, tomando ocasión de la carta del rey al concilio.

Entre tanto la asamblea, con fecha 24 de octubre de 1564, ha aceptado oficial y solemnemente el Concilio de Trento en bloque. Envía a su Majestad una copia auténtica del acta, para que sirva de modelo a otros metropolitanos. No se ha adoptado ningún otro acuerdo en firme.

Lo de poner personas que examinen a los elegidos por el rey para los obispados, «es de muy grande importancia y de muy grande periudicio suyo. Dios perdone a los que lo hicieron». ¿Dónde estaba él? ¿Cómo no lo impidió teniendo tanto poder sobre el concilio? Le parece que, «ya que no le pudieron quitar el patronazgo, que es suyo y con tan justo título, por haber cobrado de manos de infieles sus reinos, han procurado de quitárselo por indirecto. Conviene que en ello se mire mucho».

Extraña que un doctor en ambos Derechos ignore que el patronato sobre los beneficios mayores vino a los reyes por concesión apostólica y no por haber recuperado España de manos de los moros.

Liquidado el asunto del concilio, el arzobispo se desahoga sobre su situación personal con su amigo Gonzalo Pérez, el cual le había escrito que, por hacerle merced, se holgaba de hallarse en una consulta que iba a tener lugar en Segovia, indicándole que el arzobispo estaría bien en Cartagena, aunque estaba muy desmembrada. "Ya sé yo que vuestra merced me desea hacer mercedes y tiene muy grande razón, que con 
toda verdad no tiene servidor que con más voluntad que yo le desee servir, como lo verá por obra siempre que mandará servirse de mi persona, que no le seré jamás ingrato». Ha estado y está tan afligido en la iglesia de Tarragona, que cualquiera otra iglesia le convendrá más. Vale 9.500 ducados, pero está cargada con 5.000 ducados de pensiones y ahora le piden otros 1.500. «Vea vuestra merced cómo puede vivir un arzobispo que está siempre fuera de su diócesis sirviendo a su Majestad en una cosa o en otra, donde ha de tener casa doblada. Cartagena es muy buena cosa y junto a mi colegio y casa. Pero, como puesto que soy gallego de parte de padre y sea de parte de madre valenciano, natural de la ciudad de Origüela, la cual ciudad siempre ha tenido grandes diferencias con la ciudad de Murcia, donde está la iglesia catedral de Cartagena, y como sea emparentado en aquella ciudad, que cuasi no hay caballero que no sea mi deudo, han tenido los de Murcia de mí y de mis deudos muy grande sospecha. Y como agora estén indignados en haberles tanto dismenbrado su prelatura y dado a Origüela, y que sobre ello vean que les dan prelado de la mesma ciudad y tierra, darse han a todos los demonios, por donde tengo por cierto, que ni ellos ni yo quedaremos quietos ni descansados».

Para servicio del rey y descanso personal propio, sería más conveniente que se le señalase una pensión sobre la iglesia de Málaga. «Porque veo y es notorio, que tiene necesidad de mí en Cataluña como del pan que come, y esto sin soberbia alguna, para muchas cosas que se ofrescen de cada día. Y, si esto no fuese posible, me hiciese merced antes de Málaga que de Cartagena» con el título de patriarca. Deja el asunto en sưs manos ${ }^{39}$.

Para comprender el contenido de la carta anterior, conviene tener presente que la diócesis de Cartagena tenía su territorio cabalgando sobre Castilla y Aragón. Cartagena, la capital, pertenecía al reino castellano, Orihuela y otras villas, al reino de Aragón o, mejor, al de Valencia. Los reyes aragoneses intentaron desmembrar Orihuela y su territorio de la diócesis de Cartagena convirtiéndola en diócesis independiente para sustraerla a todo influjo castellano y evitar que las rentas de la iglesia orcelitana pasasen a una iglesia de otro reino. Alfonso $\mathrm{V}$ de Aragón puso en ello el máximo empeño, negociando unas veces con Eugenio IV y otras con el concilio de Basilea. Por fin, después de varias vicisitudes, Orihuela fue elevada a sede episcopal el 14 de julio de 1564 , cinco 
meses antes de nuestra carta, con la ayuda de Fernando de Loazes, arzobispo de Tarragona, nacido en Orihuela ${ }^{40}$.

\section{Sínodo ilerdense durante la suspensión}

Antonio Agustín no se contentó con publicar los decretos tridentinos en el coro de su catedral de Lérida el 27 de agosto de 1564, ni de aceptarlos con toda solemnidad en el concilio provincial de Tarragona (24 de oct. 1564). Durante la suspensión de este concilio quiso juntar a toda prisa un sínodo diocesano el 31 de diciembre del mismo año en orden a la observancia de los decretos Tridentinos. El cabildo ilerdense procuró con mucho empeño que aplazase la apertura unos días a fin de deliberar sobre los graves asuntos que se iban a abordar en la próxima asamblea. Entre otras cosas alegaron que durante el concilio provincial, que estaba suspendido, no se podía ni debía celebrar ningún sínodo diocesano. Ellos no consentían en que se tuviese otra congregación para tratar de las cosas del Concilio de Trento, sin que primero supiesen si era del agrado del rey, «pues es cierto que quedó ofendido de la provincia reunida en Tarragona», es decir de la celebración del concilio provincial (24 dic. 1564). Estas y otras razones no bastaron para detenerle en su propósito.

Entonces los canónigos elevaron sus quejas al metropolitano de Tarragona acusando a su obispo de querer supeditar y someter ante todo a su cabildo, después a toda su diócesis y finalmente a toda Cataluña, pretendiendo hacerse supremo y absoluto, sin querer reconocer al arzobispo de Tarragona como superior, pues sin causa ni razón justa no se ha querido contentar con lo que se trate en el concilio provincial, ahora suspendido. Sólo le mueven sus intereses particulares aunque alega unos motivos colorados y aparentes, ya que dice que, como él se halló a la conclusión del concilio de Trento podría inculparle el papa de ocioso y descuidado, con lo cual parece que trata a los restantes prelados de Cataluña de remisos e inobedientes a la Sede Apostólica y principalmete al metropolitano de Tarragona, que es cabeza de todos los prelados del Principado, bajo cuya guía e instrucción es justo que estén todos los obispos de la provincia.

40 DHEE. Suplemento I (Madrid 1987) 206 (J. Goñi G); DHEE III 1836 (V. López); J.R. GEA, Páginas de la historia de Orihuela. El pleito del obispado 1383-1564 (Orihuela 1900) 142; Españoles en Trento, 346, nota 700. 
Muchos canónigos y después los diputados por el cabildo leridano han suplicado a su obispo que aguarde a lo que hagan los otros prelados de Cataluña en estos negocios, que no se singularice entre todos, que tenga miramiento a lo que haga y mande el metropolitano o que consulte con él lo que convenga hacer. Se le han puesto delante infinitos inconvenientes que pueden seguirse. Pese a todo, no estimando cuantas apelaciones han interpuesto los canónigos ni estimando la autoridad de los jueces ad quos, ha pasado adelante y ha cerrado su sínodo. Y continuará moviendo disensiones y escándalos, si el metropolitano no toma cartas en el asunto y le para los pies, como se lo piden (30 dic. 1564).

En el sínodo diocesano se hicieron tres cosas principales: publicar el decreto de aceptación del Concilio de Trento y anatematizar las herejías, etc.; promulgar el decreto de residencia de los beneficios curados y, por último, nombrar examinadores para los que sean provistos de los beneficios que vaquen. El cabildo de Lérida se le opuso en todo y por todo, al principio, al medio y al fin. Algunos abades y rectores aceptaron una cosa y otra no. La mayoría respondió, en cuanto a la aceptación del Concilio Tridentino, que se refería y adhería a lo hecho en el concilio provincial y no en otra parte. En cambio consintieron en el nombramiento de examinadores. «De modo que todo su hecho, según el parecer de nuestros abogados, es nulo».

El 8 de febrero de 1565 el capítulo ilerdense en carta a su procurador en Roma le comunicaba que no acertaban a comprender el comportamiento de su obispo en lo relativo a los decretos tridentinos, «porque sabemos de cierto que todos los restantes obispos de Cataluña están parados, disimulando muchas cosas, hasta que se sepa lo que mandarán su Santidad y el Rey nuestro señor en lo relativo a las costumbres de cada patria y él solo se remueve. Es cosa muy áspera que nuestro capítulo sea el único tenido por más digno de reprensión y de castigo». Y a su procurador en Madrid, Pablo Pla, canónigo de Barcelona, le escribieron: «Vuestra merced entienda que nuestro Sr. Obispo dice y pretende que la prorrogación de la provincia no le lleva a que no pueda ejecutar él en su obispado los decretos del Concilio y así lo hace tan de hecho y con tanto rigor, que no se puede soportar. Pretende más todavía, que en esto no ha de obedecer a la provincia ni al Sr. Arzobispo, nuestro metropolitano, como de hecho no le obedece ni obedecerá en nada ni por nada».

Ante las reiteradas quejas del cabildo ilerdense, el metropolitano acabó por despachar sus letras inhibitorias, mandándole suspender la 
ejecución de lo decretado en su sínodo y enviarle todo el proceso (1 marzo 1565). En el mes de agosto aún no había obedecido ${ }^{41}$. En este punto se mostró celoso, arrogante y prepotente. Miraba a todos los demás por encima del hombro. No respetaba concordias ni compromisos contraídos.

\section{LA FASE BARCELONESA (1565)}

\section{La reapertura}

Como queda dicho, el arzobispo fijó la reapertura del concilio provincial para el 7 de mayo de 1565 , reservándose el derecho de modificar la fecha y el lugar. Y usó de ese derecho en ambos puntos. Los trabajos se reanudaron, no en Tarragona sino en Barcelona como lugar más céntrico y cómodo de todo el principado. Concretamente en la sala capitular de la catedral ${ }^{42}$.

En cuanto a la prorrogación (término equívoco) habría tenido lugar el 12 de octubre de 1565 , según el P. Serrano ${ }^{43}$; pero se trata de una interpretación incorrecta de la fórmula usada para indicar la celebración de una sesión o congregación, fórmula utilizada también el 28 octubre 1564 antes de la suspensión ${ }^{44}$. Tres documentos oficiales llevan la fecha del 5 de octubre de 1565 y uno de ellos supone varios días de trabajo ${ }^{45}$. Luego el concilio venía funcionando bastantes días antes del 12 de octubre de 1565 . Veamos si es posible precisar más.

El 21 de julio del mismo año el obispo de Elna, Lope Martínez de Lagunilla, nombró procuradores que asistiesen en su nombre al concilio provincial que iba a celebrarse en Barcelona, hasta que él llegase en persona $a^{46}$.

41 VillanUeVA, Viage 17, 62-67 y Apéndice XXII-XXV, pp.272-276.

42 Carta del nuncio Castagna al cardenal Altemps (24 oct. 1565) en L. SERRANO, Correspondencia diplomática entre España y la Santa Sede durante el pontificado de San Pío V (Madrid 1914) I 26 y 27, nota 1.

${ }^{43}$ Ibid., 27, nota 1.

44 Apéndice $n^{\circ} .7$.

45 Apéndice 17 (decreto); TEJADA VI 122-123 (carta al rey) y 123-127 (epistola sobre el conyugio).

46 Españoles en Trento, 743. 
El 15 de agosto la comisión de los concilios provinciales, reunida en Segovia dio luz verde para que en nombre del rey interviniesen en los concilios el conde de Morata en el de Aragón, el de Aytona en el de Cataluña y el de Gayano en el de Valencia. Cada uno de ellos tendría un letrado asesor, que no intervendría en los concilios. Nunca se menciona el asesor del conde de Aytona ${ }^{47}$.

El 30 de agosto el rey comunica que, en cumplimiento de lo ordenado en el concilio de Trento, «se ha hecho, con nuestra sabiduria y voluntad, por los metropolitanos destos mis reinos la convocación de los concilios provinciales». No dice para cuándo ${ }^{48}$. En un principio la apertura de los concilios se fijó para la fiesta de San Bartolomé, 24 de agosto. Después para el 1 de septiembre y por fin, como último plazo, para la fiesta de la Natividad de la Virgen 8 de septiembre ${ }^{49}$.

El conde de Aytona entregó a los padres «congregados en este concilio provincial» una carta de Felipe II del 3 de septiembre de 1565, según consta por la contestación datada el 5 de octubre del mismo año ${ }^{50}$.

Todo esto nos lleva a la conclusión de que el concilio de Tarragona se reanudó en Barcelona el 24 de agosto o a principios de septiembre de 1565 .

Presidió las sesiones el metropolitano Fernando de Loazes bajo la vigilancia del conde de Aytona, legado regio, provisto de las correspondientes instrucciones, que suponemos serían comunes a los demás embajadores: unas del 29 de agosto de 1565, ignoradas de la curia romana, y otras de 6 de octubre del mismo año, que llegaron clandestinamente a Roma, provocando un revuelo impresionante ${ }^{51}$.

\footnotetext{
47 MARÍN, 123122

48 Ibid., 126.

49 Ibid., 122-123.
}

so TEJADA VI 122-123

51 SERRANO I 30-32, 38-41 y 136-138; MARíN, 84. El papa Pio V llegó a expedir unos breves a los metropolitanos entre ellos al de Tarragona, para que no permitiesen intervenir en los concilios a seglares, aunque fuesen embajadores; pero eran menos enérgicos de lo temido y llegaron tarde (11 abril 1566), cuando hacía muchos días que los concilios se habían concluido, excepto el de Salamanca que en aquel momento también debía de estar clausurado o a punto de serlo. Por eso el nuncio se abstuvo de entregarlos (MARÍn, 88; SERRANO I 


\section{Caras nuevas}

Entre los obispos presentes en Barcelona sólo se observa una cara nueva: el obispo de Gerona. Por traslado de Arias Delgado, le sucedió en la sede gerundense Pedro Carlos, prior del convento de Uclés, de la orden militar de Santiago, hermano del marqués de Aguilar, comendador de la misma orden. La observancia era muy rigurosa en el convento de Uclés. Se levantaban a maitines a media noche. En Gerona el nuevo obispo erigió el seminario, guardó una perfecta armonía con su cabildo, promovió el cumplimiento de los decretos tridentinos y se mostró un celoso predicador de la Palabra Divina. Siguiendo el ejemplo de su antecesor, discrepó de la mayoría en puntos importantes, juntamente con los obispos de Lérida y Tortosa, y el abad de Villabertrán ${ }^{52}$.

Al arzobispo y a los obispos de Lérida, Barcelona, Elna, Tortosa, Urgel y Vich, acompañaban el 12 de octubre de 1565 los abades del Stany, Galligans, San Cugat del Vallés, Ripoll, Poblet, Besalú, San Benito de Bages, Montserrat, Villabertrán, Labaix y San Lorenzo del Monte cuyos nombres se omiten. Y los reverendos Rafael Juan Gili, canónigo y síndico del cabildo de Tarragona; Pedro Pablo Zaragoza, canónigo y síndico del cabildo catedral de Barcelona; Francisco de Castellvell, canónigo y síndico del cabildo catedral de Lérida; Pedro Traver, canónigo y síndico del cabildo de Gerona; Rafael Domenech, canónigo y síndico del cabildo de Vich; Jaime Cerveró, arcediano de Corbera, canónigo y síndico del cabildo de Tortosa; Pedro Spin, arcediano mayor, canónigo y síndico del cabildo de Urgel; Miguel de Homs, abad de Arlés, canónigo, sacrista y síndico del cabildo de Elna; Jaime Moragues, procurador del Abad del Stany y prior de Santa Ana de Barcelona; Fray Francisco de Tordelaguna, procurador del abad de Montserrat; Fray Raimundo Sopena, síndico y procurador del monasterio de la O, sede abacial vacante; Lorenzo Ysalguer, procurador del abad de San Juan de las Abadesas y Fray Juan de Guzmán, procurador y ecónomo del monasterio de San Victorián, sede abacial vacante.

Con relación a la lista de 24 de octubre de 1564 faltan los representantes de San Vicente de Cardona (Urgel), Santas Creus (Tarragona), San Saturnino de Tabérnoles (Urgel), San Lorenzo de Bagano (Urgel), San Jaime de Calaf (Vich), Santa María de Campo 
(Elna) y San Vicente de Roda (Lérida). En cambio en Barcelona aparece el abad de Labaix, que no estuvo en Tarragona ${ }^{53}$.

\section{Carta del concilio al rey}

Estando congregados en el concilio provincial, el conde de Aytona les entregó una carta del rey del 3 de septiembre de 1565 con la que recibieron muy gran merced y consolación, viendo el cristianísimo celo de su Majestad y los trabajos que se tomaba para evitar que se introdujesen tan dañosos abusos en la Iglesia Católica so color de reconciliación de los herejes. «Por la carta de vuestra Majestad habemos entendido lo que por parte de algunos príncipes de Alémania se procura con su Santidad acerca del conyugio de los sacerdotes, y ha sido el dolor que ha penetrado nuestros corazones más de lo que podríamos encarecer a vuestra Majestad, así por ver la pena en que vuestra Majestad está puesto y los grandes cuidados que de esto se le han recrecido, como en considerar el grande danyo que de condescender su Santidad a peticiones tan inicuas podría suceder». El rey solía indicar lo que había de contener la carta al papa, y exigir el envío de la minuta con correo expreso «para que antes que la firmen, la mandemos ver y advertirles de lo que paresciere convenir»).

Le remiten copia de la carta que han escrito al papa a fin de que no ceda en un asunto tan peligroso, «que en solo pensar los grandísimos danyos y inconvenientes que desto podrían seguir, nos tiene puestos en muy grande aflicción. Y por este efecto, habiendo por gracia de Dios en esta provincia grande celo de cristiandad, habemos tenido por bien de poner muy grande cuidado que estos negocios estén secretos, y fuera de las congregaciones en ninguna manera se hablen por no causar desasosiego en los ánimos de algunos y más en los ignorantes.

De lo demás que toca a las cosas de este santo concilio y a la execución del general de Trento, en otra daremos a V.M. larga cuenta; y se lo podrá también dar el conde de Aytona, al cual, como a persona tan principal en estas partes y de tanto valor y cristiandad, nos ha hecho muy grande merced vuestra Majestad en encomendarle que represente su real persona en este concilio por haberse de tratar en él, conforme a lo que manda el de Trento, cosas generales y comunes a todos los estados de los poblados de este su principado» (5 oct. 1565) ${ }^{54}$. 


\section{Epístola al papa sobre el conyugio}

La epístola del concilio al papa, larguísima, contiene una vigorosa defensa del celibato sacerdotal, basada en las enseñanzas de Jesús y de San Pablo, de los santos Padres, de los concilios, especialmente del Concilio de Trento, y de toda la tradición de la Iglesia. El matrimonio no es el único remedio de la incontinencia sacerdotal. Si se cede en este punto, no sólo los alemanes sino los franceses, los ingleses, los polacos, los dacios, los godos y los demás pueblos que abundan en hombres sediciosos, pedirán la misa en lengua vulgar, la condonación de los bienes robados a los monasterios, a los edificios sagrados y a todos los sacerdotes. Luego esperarán cosas más altas. Nada tememos tanto como que el contagio se extienda por todas partes. No se deben permitir inciertas ganancias por un daño seguro. La solución preconizada como la salvación de Alemania, no va a resolver nada y los sediciosos se volverán más insolentes (5 oct. 1565$)^{55}$.

\section{¿Continuación o concilio nuevo?}

En cartas del 14 y 19 de un mes que no se especifica, sin duda septiembre de 1565, el arzobispo de Tarragona informó al rey sobre el desarrollo del concilio. La atención se hallaba concentrada en unos apuntamientos que se habían hecho en la etapa anterior. Algunos querían aferrarse a ellos. El monarca no ocultó su desacuerdo en carta, sin fecha, al arzobispo, argumentando que «aquello fue tratado con mucha celeridad y sin haber persona que por nos asistiese», no hubo ejecución de ello ni fue publicado. Por eso sería bien que de nuevo se volviese a tratar con más discusión y acuerdo, atendiendo vos y procurando, según escribimos al conde de Aytona, que sea de la manera que por las instrucciones se ha advertido, teniendo muy grande miramiento en encaminar y guiarlo todo según la intinción que por aquéllas tenéis entendido y sin salir dellas, que al nuestro lugarteniente escribimos que os ayude en todo lo que fuere necesario, y si el negocio requiere, que consulte algunas cosas con los de la Rota, pidiéndoselo vos o el conde que así lo haga. $\mathrm{Y}$ de todo lo que sucediere nos daréis particular aviso, que en ello nos daréis mucho contentamiento ${ }^{56}$. 
El interés del rey en manejar el concilio provincial por medio de su legado y del flexible arzobispo, parece indicar que se trata de algún asunto relacionado con la jurisdicción real. Felipe II no toleraba que ningún concilio provincial entrase en ese terreno vedado. ¿Se aludirá al examen de los elegidos por el rey para los obispados o al memorial o memoria-les de dudas destinados a la consulta del papa?

Veamos si las advertencias anónimas, sin fecha, procedentes de la corte española, relativas a los concilios de Aragón y de Cataluña, arrojan alguna luz sobre el problema. Prescindamos de la parte referente a Aragón y vengamos a la relativa a Cataluña.

El fundamento que toman los padres del concilio provincial, que lo que ahora se hace es continuación de lo comenzado en Tarragona, «no parece que se debe buenamente negar». Con todo si se pudiese buenamente encaminar, que los actos primeros de la aceptación y de lo demás, a título de satisfacer a los que dudasen de esto, se tomasen a hacer y fuesen desde ahora como principio, parece que sería conveniente para debilitar el fundamento que toman los que quieren afirmarse en lo hecho.

Parece aludir a la resolución de poner examinadores de los candidatos episcopales presentados por el rey. Pero a continuación apunta al memorial o memoriales de dudas, ocasionadas por algunos decretos tridentinos.

En caso de que esto no se pueda encaminar o no parezca conveniente, en lo referente a los puntos que están asentados para consultarse, aunque sea continuación, parece que pueden tratarse de nuevo, pues, a juzgar por los autos, no recayó sobre ellos decreto ni determinación del concilio. Se trata únicamente de un memorial y apuntamiento hecho para consultarlo. $\mathrm{Y}$, aunque hubiese habido decreto o determinación del concilio, no siendo para determinar las cosas allí contenidas, sino solo para efectos de consulta, no impide que se traten de nuevo ni que se reformen o muden, ya que se procedió con tan poca discusión y con tanta celeridad, y sin la intervención de un legado regio. Según son los puntos, importa mucho que no se dé aquello por resuelto. Y teniendo el arzobispo de Tarragona tanta jurisdicción y autoridad en este negocio del concilio provincial, parece que podrá ordenarlo y enderezarlo así.

Si no se logra que se torne a tratar o si se trata «afirmándose en lo que han dicho, será muy importante que esta consulta venga a manos de su Majestad y que por su medio se examine conforme a lo contenido en 
el Memorial de advertimientos, y esto en cualquier estado que el negocio tenga, parece que habrá lugar». No se ve claro a qué punto se alude del Memorial de advertimientos del 10 de octubre de 1565.

Los autores del memorial sólo buscan que la consulta al papa suspenda la ejecución de los decretos tridentinos hasta que Roma responda. En esto «ni tienen razón ni se debe de ninguna manera permitir... Hase de mirar mucho cómo esto se trata y que en lo que toca a la execución, ni se ha de parar en el efecto ni se ha de dexar de tratar de todo los dichos cabos y puntos para lo que toca al entretanto ${ }^{57}$. Al parecer, andaba de por medio un memorial que desconocemos.

La campaña de descrédito, desencadenada por la corte contra la primera fase del concilio provincial de Tarragona sólo porque previamente no se había pedido permiso al rey y no lo había controlado un legado suyo, no produjo ningún resultado claro. Era absurdo pretender que el concilio renovase la aceptación del Concilio de Trento, hecha con la máxima solemnidad el 24 de octubre de 1564. Los decretos aprobados durante la primera etapa permanecieron firmes. Afirmar que «se procedió con tan poca discusión y con tanta celeridad», carece de base.

\section{Nuevos decretos}

El concilio se aplicó a continuar el análisis de los decretos tridentinos que creaban dudas o dificultades. El 5 de octubre el concilio se ocupó de la reforma de las monjas. Fuera de algunos conventos de clarisas y dominicas, en los que se guardaba una perpetua y estrecha clausura, en los demás - benedictinas, cistercienses, agustinas y San Juanistas- no sólo no se guardaba la clausura, sino que las religiosas pretendían que no se las podía obligar a un estrecho encierro que nunca habían profesado. Por otra parte, tendrían que reformar los edificios por dentro con máximos gastos que los monasterios no podían soportar, puesto que sus rentas apenas llegaban para vivir pobrísimamente. En vista de todo ello el concilio provincial acordó suplicar al papa que se dignase declarar qué es lo que debía hacerse. Discreparon los obispos de Lérida y Elna y el abad de Villabertrán ${ }^{58}$.

Después tocó el turno a los canónigos regulares de San Agustín, tan numerosos y tan diversos en Cataluña. Como sólo el papa podía eliminar 
las dificultades causadas por ciertos decretos tridentinos, los canónigos pidieron que en nombre de todo el concilio se consultase sobre ellas al sumo pontífice (11 octubre 1565) ${ }^{59}$.

El día siguiente, 12 de octubre, después de una larga discusión, se acordó consultar al papa sobre la cuestión de la residencia de los inferiores y que el arzobispo de Tarragona y el obispo de Barcelona, con la ayuda de las personas que ellos escogiesen redactasen la consulta y la presentasen en la primera congregación. Los obispos de Gerona, Lérida y Tortosa y el abad de Villabertrán votaron en contra de la proyectada consulta ${ }^{60}$.

E1 20 de octubre se terminaron de copiar los decretos del concilio en sus dos fases y algunos disentimientos. Todo se envió a la corte, sin duda a petición del rey ${ }^{61}$.

\section{Informe del nuncio sobre el concilio}

Cuatro días más tarde el nuncio de España, Juan Bautista Castagna informaba a Altemps desde Barcelona: Los reunidos en el concilio provincial, «al presente están en estas dificultades sobre la ejecución del Concilio Tridentino. Primero, que estando estatuido que se resida en las parroquias, qué se hará con aquellos que junto con una parroquial, tienen un canonicato o dignidad, pero que no quieran perder los frutos del canonicato o dignidad, sobre todo si se tiene en cuenta que la mayor parte consisten en distribuciones cotidianas.

Segundo, que en esta provincia hay muchos monasterios y lugares de regulares, en los cuales hay muchas porciones que se han solido dar y encomendar a clérigos seculares y así están al presente. Y diciendo el concilio que omnia bona regularium sint communia, esos regulares instan para que dichas porciones se vuelvan comunes, no pareciéndoles honesto que una parte de las cosas de sus monasterios sean comunes y otras no.

La tercera parte gira en torno de las monjas que en su profesión no han prometido o jurado clausura. Por eso no les parece honesto estar obligadas a otra cosa que a lo que han profesado. Dicen que no están comprendidas en el concilio y que por eso no quieren ser encerradas en

61 Apéndice $n^{\circ} .21$. 
clausura. Y tanto los canónigos como las monjas piden recurso a su Santidad para que declare la mente del concilio sobre el particular. - Y por semejante manera sobre la pluralidad de los beneficios curados, que son de tenuísimos frutos y no sufren unión y otras cosas semejantes que también en Italia crean grandísima dificultad. En este tiempo parece que casi todos los concilios provinciales de España se están celebrando. Hasta ahora no he podido entender si el hacerlos todos al mismo tiempo encierra algún misterio» (24 oct. 1565$)^{62}$.

Altemps contestó a Castagna: «Acerca de las dificultades que se habían movido en el sínodo provincial de Tarragona en la ejecución del Concilio de Trento sobre aquellos tres puntos, si se recurre acá..., nuestro señor no dejará de darles la declaración que conviene siendo cosas ya bastante examinadas y resueltas por estos señores de la Congregación» del Concilio (23 nov. 1565) ${ }^{63}$.

\section{Dudas movidas en el concilio}

La corte española había advertido que se elevarían memoriales al papa pidiéndole que interpretase $o$ declarase o derogase o mudase 0 alterase los decretos tridentinos. Convenía que el metropolitano estuviese alerta para excusarlo en lo posible $(1565)^{64}$. Pero quizá no previó que se dirigirían memoriales al rey solicitando mandase declarar lo que sería servido se practicara. Esto es precisamente lo que ocurrió. Después de trasladado el concilio tarraconense a Barcelona, los prelados de Cataluña formularon dos clases de dudas, que en parte ya conocemos: unas relativas al principado y otras generales para toda España.

Las primeras venían a decir lo siguiente: En este concilio provincial cada obispo ha nombrado jueces apostólicos, a quienes el papa ha de encomendar las causas que vayan a Roma de la misma diócesis. Se duda si se enviarán a Roma los nombres de los jueces. Si no se envían, las causas se juzgarán en Roma. Si se envían se pondrá en tela de juicio la imparcialidad de los obispos al enviar una y no otra.

El Concilio de Trento manda se nombren examinadores para la provisión de los beneficios curados. ¿Habrá que convocar sínodos 
diocesanos a tal fin? En caso negativo, las rectorías que vayan quedando vacantes, no se podrán cubrir.

Igualmente dispone el Concilio Tridentino que de aquí en adelante no haya más que dos padrinos en el bautismo y en la confirmación. «Hay duda si se publicará y mandará esto. Y también lo del matrimonio clandestino por las diócesis, que será todo prohibido y anulado».

Por último, si mientras el concilio está abierto, «mandarán los obispos se executen y guarden los decretos de la residencia y las clausuras y reformaciones de los monasterios $){ }^{65}$.

Los «perlados de Catalunia» querían que el rey resolviera estos problemillas. Felipe II se preguntaría qué pintaba el concilio provincial, si no sabía solucionarlos por sí mismo.

La segunda serie de dudas contenía más enjundia. En algunas iglesias catedrales hay ordenaciones apostólicas o reformas hechas por los papas o constituciones confirmadas por ellos que disponen que las dignidades y preposituras se confieran a los canónigos de las mismas iglesias y no a otros. Como el Concilio de Trento manda que al que tiene un beneficio, no se le dé otro, sino en cierta forma; se duda si esta nueva disposición afecta a los canónigos para que no puedan tener las dichas dignidades, pavordías o beneficios que por concesiones apostólicas se han de conferir a ellos mismos y no a otros.

El Tridentino dispone que todos los curas residan personalmente en sus parroquias. «Es la duda si en esto son comprehendidos los canónigos de iglesias catedrales... que tienen rectorías». Como están obligados a residir en la catedral, parece que no deben residir en las parroquias. $\mathrm{O}$ si estarán obligados a residir sólo en la rectoría o bien a dejar la canonjía o la parroquia.

Finalmente muchos monasterios y conventos de San Benito y San Agustín tienen casi todos los oficios claustrales, como camarería, enfermería, etc., en poder de clérigos seculares, provistos por la Sede Apostólica. Así estas rentas y estos oficios están fuera de casa, al paso que los residentes en el convento hacen vida común. Estos dicen que, para cumplir lo que el Concilio de Trento les manda, tienen que volver 
a casa los oficios y las rentas, sin que en adelante se puedan proveer en personas seculares ${ }^{66}$.

\section{La consulta a Roma}

Por fin, la consulta fue elevada a la Santa Sede. Según Jaime Villanueva, la consulta se efectuó en 1564: «Respecto de los cánones que tocaban en la reforma de las costumbres, como en esta provincia las hubiese antiguas y muy respetables, y entendiesen que ni era voluntad del papa ni del rey quitarlas ni abrogarlas sin madura deliberación, resolvieron dirigir a su Santidad por mano de su Majestad cinco artículos de dudas, los cuales el rey aprobó y suspendió en el interim la conclusión del concilio provincial hasta la octava de Pascua del año siguiente $1565 »^{67}$.

Este pasaje no encaja con todo lo que llevamos expuesto a base de documentos libres de toda sospecha.

La consulta se verificó sin la intervención del rey, enviada directamente a Roma por el cardenal de San Sixto, Hugo Boncompagni, futuro papa Gregorio XIII, que como legado pontificio hizo su entrada en Barcelona el 19 de octubre de 1565, según unas fuentes, o dos días después, según otras. Abarcaba 14 artículos. Fue publicada por José Rius Serra, con el título Dudas del concilio tarraconenese de 1565, Revista española de Derecho Canónico 8 (1953) 601-603, y reproducida en Miscelanea Mons. José Rius Serra (San Cugat del Vallés 1965) 10211024. La transcripción está tomada del original, que se conserva en el Archivo Vaticano y lleva por título Dubia concilii Tarraconensis circa Concilium Tridentinum, missa a cardinali S. Sixti 23 octobris 1565.

En ocasiones la transcripción parece incorrecta y sin sentido coherente. Sin embargo lo más sospechoso es la fecha. ¿Cómo es posible que un día después del envío de la consulta el nuncio Castagna, que estaba en íntimo contacto con el cardenal, no supiera nada de un asunto tan importante, y que Altemps ignorara la llegada de la consulta el 23 de noviembre? Creemos por tanto que la fecha de envío, 23 octubre 1565 , está posiblemente equivocada. Sabido es que las ediciones de

66 Apéndice $\mathrm{n}^{\circ} .15$.

67 VillanueVa, Viage 17, 63. 
documentos, hechas por Rius Serra, no se pueden considerar como $\operatorname{modelos}^{68}$.

La consulta recoge las principales dudas planteadas por el concilio provincial, aunque de una manera más concisa. He aquí su contenido.

1. Si los que poseen dignidades o canonicatos o porciones $\mathrm{u}$ otros beneficios en iglesias catedrales o colegiales, y al mismo tiempo poseen, por dispensa o de otra manera, antes del Concilio de Trento, rectorías $\mathrm{u}$ otros beneficios curados están obligados a residir en los beneficios curados más bien que en las otras iglesias. Respuesta: Tienen obligación de residir en los curados y no se excusan por razón de otro beneficio.

2. $\mathrm{Si}$ los residentes en los curados del caso anterior lucran los frutos de otros beneficios que se dan a los ausentes o también los que lucran los presentes y las distribuciones cotidianas. - Con tal de que residan en los beneficios curados, ganan los frutos de los otros beneficios que suelen darse a los ausentes, salvo las distribuciones, las cuales, sin embargo, también se dan en el caso de la Ses.22, c.3 al fin.

3. Si los así ausentes y residentes en los curados pueden ser obligados a servir los otros beneficios en los que no residen y si puede procederse contra ellos a tenor del capítulo XII, sess.23 y otros decretos del mismo concilio. - No pueden ser obligados a los servicios personales, porque no depende de ellos, ya que la ley prohibe abandonar la cura de almas.

4. Si todó lo dicho se puede aplicar a los abades y a otros que poseen beneficios regulares o seculares con cura espiritual y jurisdicción, y al mismo tiempo obtienen rectorías o iglesias parroquiales, con dispensa, o también dignidades o canonicatos con las mismas abadías y otros beneficios curados. - Debe observarse lo dicho, porque ante todo debe residirse en la parroquial.

5. Si los que obtienen con dispensa dos beneficios curados están obligados a resignar uno de ellos, atento que no puede residir en ambos, o puede elegir el beneficio donde quiere residir, o puede variar, - No está obligado, a no ser que se trate de dos parroquiales, Sess.24, c.17. Y puede elegir o variar, con tal que resida siempre en uno de los dos.

68 DHEE, Suplemento I 649-650 (J. Goñi G.). El cardenal de San Sixto vino a España por el asunto de Carranza, procesado por la Inquisición, y regresó a Roma el 29 de diciembre de 1565 . 
6. Si por los decretos De residentia y otros aprobados bajo Pío IV, están derogadas las dispensas aprobadas bajo Paulo III y Julio III, sobre todo las dispensas a tenor del capítulo. - Acerca de varias parroquiales está derogada la dispensa, Sess.24, c.XVII. En otros beneficios la residencia está en el curado, como arriba se ha dicho.

7. Si los que poseen dos iglesias parroquiales tenues están obligados a dejar una de ellas, ya estén cerca o lejos entre sí. - Están obligados a dejar una de las dos.

8. Si en virtud del decreto sobre pluralidad de beneficios, al que tiene dos beneficios insuficientes para su sustento, se le puede dar un tercero que o por sí sea suficiente o juntamente con otro u otros, y si así se le pueden dar otros muchos. - No se prohibe darle.

9. Si existiendo costumbre o estatuto de que las dignidades o preposituras se confieran únicamente a canónigos, no se requiere dispensa para obtenerlas a la vez. (La redacción es confusa, como también la respuesta). - (Se de a cualquiera), salvo de costumbre.

10. $\mathrm{Si}$ a un canónigo se le puede conferir una dignidad o prepositura $\mathrm{u}$ otros beneficios, aunque cada uno de ellos sea suficiente para su sustento. - No se puede, porque cada uno de ellos exige la residencia personal.

11. Si los abades, priores, canónigos regulares y otros que obtienen de la Sede Apóatólica en título o en encomienda sus beneficios, están obligados a guardar la pobreza y la comunidad de cosas con los otros monjes y pueden ser obligados a ello por sus superiores a tenor de los decretos De regulares en los capítulos primero y segundo. - No parece hablarse de encomiendas. De los que tienen título, si son obedenciarios, están obligados a la comunidad de bienes y a la pobreza. Si tienen título de una iglesia no sometida al monasterio, son considerados como clérigos seculares y dejan de ser monjes del mismo monasterio; de otra manera no es lícito, sino como peculio,

12. Si la clausura de las monjas está encomendada a los obispos en cualesquiera monasterios, incluso en los no sujetos a su jurisdicción. Está encomendada de una manera general.

13. Si la licencia de salir ha de ser aprobada por los obispos, incluso para los monjes sujetos a monasterios. - Debe ser aprobada. 
Segunda. A su Magd. Del Arçobispo de Tarragona a XII de octubre de 1564

Sa.Cathoca.R.Magd.

Después de hauer scripto a V.Magd, la que va con ésta, como en este provincial concilio se començase a tratar de la forma y modo que se ha de tener en el examen e inquisición que se ha de hacer de las personas que serán nombradas y elegidas para obispos y prelados de las yglesias cathedrales de cada prouintia, viendo yo que esto toca y pertenece prinçipalmente a V.Magd., que paresçe le quieren poner sobrestantes y deputar personas que vean y examinen si las tales personas que V.Magd. nombrare, son hábiles y suficientes, dixe a todos los congregados, que una cosa tan ardua y tan ymportante no se debía tratar sin primero dar a V.Magd. cuenta y razón della. Y, aunque en semejantes congregaçiones nunca falta quien sea en algo contrario, todauía todos los obispos y quasi todo el conçilio han sido conmigo y ansí scriuen por la posta a V.Magd. sobrello. V.Magd. mandará ver y reconosçer el decreto tridentino que está en la sessión veinte y quatro y es el capítulo primero y mandará lo que más seruido fuere sobrello.

Ya es, señor inuictísimo, de derecho, que los obispos examinen si son hábiles los presentados por los patronos en los beneficios simples y curados, y el papa examina los que son presentados para obispos. Y, pues esto se haze y acostumbra hazer en Roma, no me paresçe que hay necesidad de poner examinadores en Spaña. V.Magd. mandará proueer lo que más a su seruicio conuenga. N.S. la Sa.Cathca.y R. persona de V.Magd. guarde y con triumpho y victoria contra los enemigos de su Real corona conserue. Desta su çiudad de Tarragona, a XII de octubre de 1564.

(Archivo General de Simancas, P.R., 22, 17. I

3.

12 octubre 1564

Tercera. A su Mjd. Del Arçobispo y concilio provincial de Tarragona de XII de octubre de 1564.

Sa.Cathca.y R.Magd.- Estando como estamos aquí ayuntados por reçebir y cumplir lo que en el sacro tridentino conçilio ha sido statuido y ordenado, auemos visto que, entre otros decretos dél, está un decreto en la çessión veinte y quatro en el capítulo primero De reformatione, que dispone y manda que en el conçilio prouinçial se dé y ordene la 
forma que conuendrá y paresçerá se deue tener para el examen o ynquisiçión que se ha de hazer de las personas que serán nombradas y promouidas a yglesias cathedrales, la qual se aya de embiar al papa para que a su arbitrio se aprueue, effectúe y cumpla. Y, porque a V.Magd, como patrón y señor ques, pertenesçe nombrar los prelados para las dichas cathedrales yglesias y es de creher mandará nombrar tales personas quales conuiene al buen gobierno y regimiento dellas, nos ha paresçido no hazer acerca desto cosa alguna sin que primero lo consultemos con V.Magd. y nos mande lo que más a su real seruicio cumpla. Suplicamos a V.Magd., pues este mensajero no va por otra cosa, sea seruido de mandarle expedir luego, porque esta congregación estará suspensa hasta que de V.Magd. tengamos respuesta. N.S. la Real persona de V.Magd. guarde y con triumpho y victoria contra los enemigos de su real corona conserue. De Tarragona, a XII de octubre MDLXIIII'.

Recepción del Concilio Tridentino hecha por el concilio provincial de Tarragona.

In nomine Domini. Amen. Per hoc presens publicum instrumentum cunctis temporibus perpetuo valiturum pateat uniuersis et sit notum, quod anno a Nativitate Domini millesimo quingentesimo quadragesimo quarto, die vero martis vicesima quarta mensis octobris intitulata, congregato sacro provinciali concilio Tarrachonensi in capella sacratissimi Corporis domini nostri Jesu Christi in claustro ecclesiae Tarrachonensis constructa, in loco ad hoc per Illmum. et Rmum. in Christo patrem et dominum dominum Ferdinandum de Loazes, miseratione diuina sancte Tarrachonensis ecclesiae archiepiscopum assignato et deputato, existentibusque ibidem simul cum prelibato Illmo. et Rmo. domino Archiepiscopo Rmis. dominis episcopis, abbatibus, prioribus aliisque prelatis, syndicis et procuratoribus infrascriptis provincialiter, ut prefertur, congregatis, conciliumque provinciale pro infrascriptis et aliis negociis facientibus et celebrantibus, in mei Damiani Gili, notarii publici Tarrachonensis ac dicti sacri provincialis concilii scribe, testiumque infrascriptorum ad hoc specialiter vocatorum, rogatorum et assumptorum presentia, prefatus Illmus. ac Rmus. dominus archiepiscopus ac Rmi. domini episcopi, abbates, priores, syndici et procuratores infrascripti insequendo dispositionem decreti capite secundo reformationis sessione 
vicesime quinte sacri oecumenici generalis Concilii Tridentini incipientem Cogit temporum calamitas, etc., unanimes et conformes et nemine discrepante nomine eorum proprio ac plurium suorum infrascriptorum respective et totius Tarrachonensis provincie, prout inferius latius et plenius continetur, fecerunt palam et publice receptionem de omnibus et singulis a prefata sancta Synodo Tridentina deffinitis ac statutis ac etiam omnes simul et unusquisque eorum veram obedientiam sanctissimo domino nostro Papa Pio quarto, eiusque successoribus et eius sancte Sedi Apostolice sponderunt et professi fuerunt ac herezes omnes detestati fuerunt et anathematizaverunt, prout in quadam scriptura per ipsos michi dicto notario et scribe tradita latius et plenius continetur, mandaueruntque, petierunt et requisiuerunt per me dictum notarium et scribam de his publicum confici instrumentum et in processu dicti sacri provincialis concilii inseri, prout in dicta scriptura lacius deducitur, que est tenoris huiusmodi.

DEO optimo maximo gratias agimus, qui temporibus nostris Ecclesiam suam sanctam tot procellis ac fluctibus agitatam, ita.deffendit ac conseruauit, ut per decreta sacri oecumenici Tridentini Concilii auctoritate Summi Romani Pontificis felicis recordationis Pauli III in Spiritu Sancto legitime congregati, atque eiusdem et pie memorie Julii Pape III, necnon Sanctissimi domini nostri Pii quarti consensu, auxilio et promotione, sub protectione gloriosissime memorie Charoli quintí imperatoris et catholici regis nostri Philippi continuati, celebrati ac conclusi et ab eodem beatissimo Pio confirmati, herezes uniuersas que non sine totius christiani orbis perturbatione in pluribus partibus viguerunt, damnauerit et improbauerit, ac veram fidem catholicam christianis omnibus ita asseruerit et apertissime declarauerit, ut eisdem sacri Concilii saluberrimis sanctionibus uniuersalis Ecclesia, quam diuina Magestas sponsam immaculatam et sine ruga sibi assumpsit, in suo splendore perseueret; mores vero corruptos ita seueritate discipline ad veterem patrum institutionem, quantum hec tempora ferre possunt, correxerit ac reduxerit, ut nichil aliud quam ut diuino auxilio iuuante eisdem vestigiis inherere possimus, desiderare queamus. Quapropter

NOS Ferdinandus de Loazes, miseratione diuina Sancte Tarrachonensis ecclesie archiepiscopus,

Arias Gallego, Gerundensis Antonius Augustinus Ilerdensis Guillermus Cassador Barcinonensis Per eandem miserationem Martinus de Cordoba Dertusensis Petrus de Castelleto Urgellensis 
Joanne de Tormo. abbas monasterii Sancti Petri Bisuldini, Ordinis Sancti Benedicti, Gerundensis diocesis,

Petrus Frigola, abbas monasterii Sancti Benedicti de Bages, Ordinis Sancti Benedicti, Vicensis diocesis,

Michael Sarrano, abbas monasterii Sancti Vincentii de Cardona, canonicorum regularium Ordinis Sancti Augustini, Urgellensis diocesis.

Hyeronimus Contijoch, abbas monasterii Sanctarum Crucum, Ordinis Cisterciensis, Tarraconensis diocesis,

Ludovicus de Ceruilione, abbas monasterii Sancti Cucuphatis, Ordinis Sancti Benedicti Vallensis, Barcinonensis diocesis,

Cosmas Damianus Ortola, abbas monasterii beate Marie de Vilabertrando, Ordinis Sancti Augustini canonicorum regularium, Gerundensis diocesis,

Thomas Costa, abbas seu perpetuus commendatarius monasterii sancti Saturnini de Tauernolis, Ordinis Sancti Benedicti, Urgellensis diocesis,

Michael de Agullo, abbas seu perpetuus commendatarius monasterii sancti Laurentii prope Baganum, Ordinis Sancti Benedicti, Urgellensis diocesis,

Paulus Pla, abbas seu perpetuus commendatarius monasterii Sancti Petri de Gallicantu, Ordinis Sancti Benedicti, Gerundensis diocesis, Michael Ferrer, prior monasterii Scale Dei, Ordinis Cartusiensis, Tarraconensis diocesis,

Jacobus Agramunt, prior monasterii Sancti Jacobi de Calaf, Ordinis

Sancti Augustini canonicorum regularium, Vicensis diocesis,

Geraldus Vilana, prior monasterii beate Marie de Campo, Ordinis canonicorum regularium Sancti Augustini, Elnensis diocesis,

Joannes de Funes, prior monasterii Sancti Vincentii de Roda, Ordinis Sancti [en blanco] diocesis [en blanco].

Raphael Joannes Gili, canonicus et syndicus Rvdi. Capituli ecclesie Tarrachonensis,

Petrus Paulus Çaragoça, canonicus et syndicus Rvdi. Capituli ecclesie Barcinonensis,

Franciscus de Castellbell, canonicus et syndicus Rvdi. Capituli ecclesie Ilerdensis,

Jacobus Ceruero, Archidiaconus de Corbera, canonicus et syndicus Rvdi. Capituli ecclesie Dertusensis,

Petrus Trauer, canonicus et syndicus Rvdi. Capituli ecclesie Gerundensis, 
Petrus Spin, Archidiaconus maior, canonicus et syndicus Rvdi Capituli ecclesie Urgellensis,

Michael Domenech, canonicus et syndicus Rvdi. Capituli ecclesie Vicensis,

Michael de Homs, abbas seu perpetuus commendatarius monasterii de Arles, canonicus et sacrista ac syndicus et eo nomine Rvdi. Capituli ecclesie Elnensis,

Martinus de Marquina, monacus et procurator Rvdi. Petri Boques, abbatis monasterii beate Marie Populeti, Ordinis Cisterciensis, Tarraconensis diocesis,

Franciscus de Tor de Laguna, monacus et procurator Rvdi. Benedicti de Tocco, abbatis monasterii beate Marie de Monteserrato, Ordinis Sancti Benedicti, Vicensis diocesis,

Laurentius Ysalguer, canonicus et procurator Rvdi. Michaelis Agullana, abbatis seu perpetui commendatarii monasterii Sancti Ioannis de Abbatisis canonicorum regularium Ordinis Sancti Augustini, Vicensis diocesis,

Jacobus Moragues, canonicus monasterii Sancte Anne Barcinonensis, procurator Rvdi. domini Caroli de Cardona, abbatis seu perpetui commendatarii monasterii beate Marie de Stagno, Ordinis Sancti Augustini, administratoris dicti monasterii Sancte Anne $\bar{B}$ arcinonensis,

Gispertus de Malars, monacus et camerarius monasterii beate Marie Riuipulli, procurator Rvdi. Bernardi Capeller, abbatis seu perpetui commendatarii monasterii beate Marie de Sarratez, Ordinis Sancti Benedicti, Urgellensis diocesis,

Joannes de Guzman, monacus, syndicus et procurator Rvdi. Conuentus Sancti Victoriani, Ordinis Sancti Benedicti, diocesis Ilerdensis, abbate carente,

Raymundus Sopena, monacus, syndicus, economus et procurator Rvdi. Conuentus monasterii de la O, Ordinis Sancti Benedicti, Ilerdensis diocesis, abbate carentis.

In capella sacratissimi Corporis domini nostri Jesu Christi, in claustris dicte nostre metropolitane ecclesie Tarraconensis constructa, loco ad hoc specialiter per nos dictum archiepiscopum deputato, prouincialiter congregati, conciliumque prouinciale facientes et celebrantes, insequentes dispositionem decreti capite secundo Reformationis çesionis vicesime quinte dicti Concilii Tridentini incipientis Cogit temporum calamitas, etc., omnes unanimes et conformes, nemine discrepante, ut veri ortodoxi ac sancte Sedis 
Apostolice filii obedientissimí, tam nominibus nostris propriis et principalium nostrorum respective et cuiuslibet nostrum quam eorum ac omnium et singulorum subditorum nostrorum et dictorum plurium respective ac totius nostre Tarraconensis prouincie, omnia et singula que a prefata sancta Synodo Tridentina definita et statuta sunt, palam et publice omni meliori modo et forma quibus melius possumus et debemus, recipimus, necnon veram obedientiam dicto sanctissimo domino nostro domino Pio papa quarto, summo romano pontifici, vero et indubitato Christi Vicario, beatique Petri, apostolorum principis successori, eiusque successoribus canonice intrantibus, sancteque eius Sedi Apostolice spondemus et profitemur, simulque herezes omnes a sacris canonibus et generalibus conciliis, presertimque ab eadem sancta Synodo Tridentina damnatas, etiam publice et palam detestamur et anathematizamus.

Et ut de hac nostra receptione, veraque obedientia et sponsione, simulque detestatione et anathematizatione, aliisque predictis, omnibus constet requirimus et mandamus per vos Damianum Gili, notarium et dicti nostri sacri concilii provincialis scribam, publicum instrumentum fieri et confici et in processu dicti nostri sacri concilii prouincialis scribi et inseri ac nobis et omnibus illud petentibus et habere volentibus tradi.

Que fuerunt acta in dicta capella sacratissimi Corporis domini nostri Iesu Christi claustri dicte ecclesie Tarraconensis die et anno predictis, presente et interueniente me, Damiano Gili, notario publico et scriba dicti sacri prouincialis concilii, pre et infrascripto, et presentibus etiam reverendis dominis Raphaele de Homs, archidiacono maiori, Ioanni Damiano Miret, succentore secundo, Raphaele Llorens, Antonio Ioanne Delgado, Antonio Daroche, canonicis dicte ecclesie Tarraconensis, Bernardo de St. Climent, rector ecclesie ville de Silua, Augustino Freza, iurium doctore, comensale, officiali et vicario generali dicti Rmi. Domini Archiepiscopi I...o ${ }^{74}$ Guier etiam comensale, Iacobo Ros, Ioanne Figols, in sacra pagina magistris, Ioanne Rosell, presbiteris beneficiatis dicte ecclesie et magnificis domno Honofrio de Seruia, in ciuitate Valentie et Ludovico Louer, domicellis in presenti ciuitate Tarrachone domiciliatis, Michaele Ioanne Çaporta, Ludovico Pons de Ycart, Francisco Osorio et Michaele Angelo Comalada, iurium doctoribus, ciuibus Tarrachone, presentibus, ad hoc vocatis specialiter et assumptis et pluribus aliis in multitudine copiosa. 
Et ego Damianus Gili, ciuis Tarrachonensis, pro Illmo. et Rmo. in Christo patre et domino domino Ferdinando de Loazes, miseratione divina sancte Tarrachonensis ecclesie archiepiscopus, eiusque auctoritate notarius publicus dicte civitatis ac sacri prouincialis concilii Tarrachonensis scriba, quia dicti sacri ecumenici Tridentini concilii receptioni, ceterisque premissis interfui, eaque sic fieri vidi et audivi et in notam sumpsi, igitur hoc presens publicum instrumentum aliena manu scriptum extraxi et confici signoque quo in scribania communi Tarraconensi utitur et nomine meo solito et consueto signaui in fidem et testimonium predictorum rogatus et requisitus.

(Archivo General de Simancas, P.R., 22,66)

4a. Copia de la carta de su Magd. al Arçobispo de Tarragona.

EL REY.- Muy reverendo in Christo padre Arçobispo, del nuestro Consejo. Dos cartas vuestras auemos recibido de XII del presente y entendido por ellas cómo auíades conuocado en esa ciudad los obispos, abades, priores y capítulos desse principado para celebrar el concilio provincial que dispone el de Trento quc se haga, para aceptar y cumplir los decretos dél. Y, aunque tenemos por cierto que vos os auéis mouido a esto con el buen zelo que nos escriuís, no podemos dexar de deziros que fuera razón que antes de determinaros a hacer una junta y congregación de tal qualidad, nos lo huuiérades auisado para saber si era sazón de hazerla, como en efecto no lo ha sido, porque el tratar de semejantes negocios ha de ser a un tiempo en esse y en los otros mis reynos Despaña, y con buena inteligencia, conformidad y correspondencia de todas partes, para que de común acuerdo se asienten como conuiene al seruicio de Dios, bien de su yglesia y destos mis reynos y súbditos dellos, lo qual se ha de hazer quando y como yo lo mandare auisar, que será presto. Y porque cumple mucho que entretanto no se pase adelante en esa congregación, scriuo al Illme. Príncipe de Melito, mi visorey desse mi Principado, que os embíe una persona que os diga lo que agora queremos que hagáis para el remedio dello, que en sustancia es que vos, lo más diestra y dissimuladamente que pudiéredes, como de vuestro, suspendáis y proroguéis la celebración desse concilio hasta después de Pasqua de Resurrección, porque en este medio os escriuiremos la orden que en él auéis de guardar, que será la misma que han de tener los otros Arçobispos que han de juntar los tales concilios prouinciales. Y porque 
el dicho mi visorey os lo declarará más en particular, encargamos os mucho que tengáis con él toda buena intelligencia y le creáis como a nos mismo en todo lo que acerca desto os escriuiere o embiare a dezir, y lo hagáis y cumpláis como de vos lo esperamos y confiamos, y como cosa que nos será muy agradable. $Y$ porque en la carta que respondemos a vos y a los demás prelados dessa congregación, se scriue lo que veréis, miraréis allá por vuestra prudencia lo que será bien que les digáis, de manera que se cumpla con ellos y se haga lo que está dicho lo mejor y más presto que ser pudiere.

Del Escurial a XXVII de octubre 1564.

Yo el Rey.- Çayas por secretario.

(Archivo General de Simancas, P.R., 22, 14, I)

5. Copia de la Carta de su Md. al Arçobispo y conçilio Prouincial de Tarragona. La original va dentro del pliego de su Magd. para el Arçobispo.

EL REY.- Muy reverendo, reverendos in Christo padres, venerables y amados nuestros. Por vuestra carta de XII del presente, auemos visto cómo os auéis juntado en essa ciudad para recebir y cumplir lo que por los decretos del sancto Concilio de Trento se ha instituido y ordenado, y lo que nos consultáis acerca de la duda que se os ofresce sobre la forma que se aurá de tener en el examen de las personas que serán por nos presentadas a iglesias cathedrales queriendo entender nuestra voluntad para proceder conforme a ella en este artículo.

$Y$ lo que a esto se nos offresce que responderos es que, aunque os agradescemos mucho el miramiento y respecto que, como tan zelosos de nuestro seruicio y de la conseruación de nuestro patronazgo y preeminencia auéis tenido en auisarnos dello, hubiéramos holgado y fuera conueniente que el juntaros y començar a tratar dessos negocios, fuera en tiempo que se hiciera lo mismo en este y en los otros mis reynos y no antes, porque procediendo todos unánimes y con buena intelligencia y conformidad de todas partes, se pudiera mejor poner en execución lo que el sacro Concilio de Trento dispone y manda, que es lo que 
queremos, pretendemos y desseamos, como sabéis y lo escriuimos más particularmente a vos el arçobispo.

Del Escurial a XXVII de octubre 1564.

Yo el Rey.-Çayas por secretario.

(Archivo General de Simancas, P.R., 22, 14, II).

Sesión de trabajo sobre la consulta que piden las monjas

Die sabbati vicesima octaua mensis octobris anno a Natiuitate Domini millesimo quingentesimo sexagesimo quarto hora secunda post meridiem ipsius diei, ad quas diem et horam huiusmodi Prouinciale concilium Tarraconense fuit prorrogatum, in dicto palatio archiepiscopali Tarraconensi post pulsationem campane maioris dicte ecclesie ad celebrationem et continuationem dicti concilii conuenerunt et presentes fuerunt sequentes:

Illmus ac Rmus. dominus archiepiscopus

Rmus. dominus Gerundensis episcopus

Rmus. dominis Ilerdensis episcopus

Rmus. dominus Barcinonensis episcopus

Rmus. dominus Dertusensis episcopus

Rmus. dominus Urgellensis episcopus

Rdus. abbas Sancti Petri Bisulduni

Rdus. abbas monasterii Sancti Petri de Bagiis

Rdus. abbas monasterii Sancti Cucuphatis Vallensis

Rdus. abbas monasterii Sancti Vincentii de Cardona

Rdus. abbas Sancti Petri de Gallicantu

Rdus. abbas monasterii beate Marie de Villabertrando

Rdus. abbas monasterii de Banyoles

Rdus. abbas monasterii Sancti Laurentii de Bagano

Rdus, abbas monasterii Sancti Saturnini de Tauernolis

Rdus. prior monasterii Scale Dei, Ordinis Cartusiensis

Rdus. prior monasterii de Roda

Rdus. prior beate Marie de Campo

Rdus. prior Sancti Jacobi de Calaf

Rdus. abbas monasterii Sancti Genesii de Fontanis

Rdus. abbas monasterii de Banyoles

Rdus. abbas monasterii Sarrateix

Rdus. prior beate Marie de Hulmo

Rdus. prior beate Marie de Campo 
Rdus. prior Sancti Petri de Clarano

Rdus. prior infra castrum de Besalu

Rdus. prior de Serrabona

Rdus. prior Sancti Iacobi de Calaf

Rdus. prior Sancti Laurentii de Monte

Rdus. prior Sancti Stephani de Orta

Rdus. Iacobus Cassador, procurator Rmi. domini Dertusensis episcopi

Rdus. Petrus Paulus Çaragoça, canonicus et sindicus Rdi. capituli ecclesie Barcinonensis.

Rdus. Michael de Olzinelles, canonicus et sindicus Rdi. capituli ecclesie Ilerdensis

Rdus. Iacobus Ceruero, archidiaconus de Corbera, canonicus et sindicus Rdi. capituli ecclesie Dertusensis

Rdus. Petrus Trauer, canonicus et sindicus Rdi. capituli ecclesie Gerundensis

Rdus. Raphael Domenec, canonicus et sindicus Rdi. capituli ecclesie Vicensis

Rdus. Petrus Spin, archidiaconus maior, canonicus et sindicus Rdi. capituli ecclesie Urgellensis

Rdus. Michael de Homs, abbas de Arles, sacrista ac canonicus et sindicus Rdi. capituli ecclesie Elnensis

Venerabilis frater Petrus Martin, sindicus monasterii Sancti Victoriani sede abbaciali vaccante

Venerabilis Ludouicus Cagarriga, sindicus et procurator monasterii Sancti Saluatoris de Breda sede abbatiali vacante

Venerabilis frater Marchus Oller, procurator Rdi. Abbatis monasterii Sanctarum Crucum

Et primo super negocio consultationis petite pro parte religiosarum monialium et supplicationum per eas oblatarum fuit conclusum quod fiat consultatio Smo. D.N. pape, non intendendo tamen in aliquo innouare, interpretari nec mutare sacra decreta sancti oecumenici Tridentini Concilii, nec ab eis et eorum exequtione recedere, cuius consultationis ac supplicationum et memoralium predictorum ordinatio fuit commissa Rmis dominis Barcinonensi et Vicensi episcopis ac Rdis. abbatibus de Bisulduno et de Populeto ac Sancti Petri Gallicantus et priori beate Marie de Campo, quorum ordinatio ac reductio antequam expediatur, in concilio legatur, cui quidem conclusioni dissenserunt Rmi. domini Ilerdensis et Elnensis episcopi.

(Archivo General de Simancas, P.R. 22, 7.0 II) 
Decreta per sacrum prouinciale Concilium Tarraconense facta super dubiis cum S.D.N. Papa consulendis, ortis ex nonnullis decretis sacri generalis oecumenici Concilii Tridentini De Reformatione.

Super residentia inferiorum

Constitutione sacri Synodi Tridentinae in XXIII sessione, cap.I, versiculi Eadem omnino, sanctissime ordinatum est omnes obtinentes beneficia curata obligatos esse ad continuam residentiam in eis faciendam sub poenis in dicto cap. appositis. Et in vigesima quarta sess. cap.XII vers. . Preterea, sanctissime etiam cauetur obtinentibus dignitates vel canonicatus et prebendas aut portiones in cathedralibus aut collegiatis ecclesiis non licere ultra tres menses ab iisdem ecclesiis quolibet anno abesse, alias puniuntur poenis in dicto cap. positis. Nullibi tamen per decreta dictae synodi Tridentinae reuocatae sunt pluralitates beneficiorum quae usque ad tempora dicti concilii inuicem incompatibilia non reputabantur: solum enim dispensationes obtinentium plures parrochiales ecclesias per cap.XVII, vers ${ }^{\circ}$. Illi vero, sess. XXIIII reuocatae censentur praefixo illas obtinentibus certo termino intra quem omnes praeter unam resignare tenentur. Quinimo dispensationes super pluralitates beneficiorum hactenus concesse sustinentur per eandem sacrosanctam synodum in cap.V, sess.VII seruata forma cap. Ordinarii de offic. ordin., lib.VI, ex quo elicitur non esse prohibitum retinere dignitatem curam animarum non habentem, canonicatum et prebendam in ecclesia cathedrali vel collegiata et quaelibet alia beneficia in dictis vel aliis ecclesiis etiam si de iure vel consuetudine residentiam requirant quoad hodie illa obtinentes simul cum unica parrochiali ecclesia predicta quoad aliquod ex illis resignandum per constitutiones dictae synodi obligatos non esse, et ita istum casum omissum esse per Concilium Tridentinum et propterea remanere in eo statu in quo ante dictum Concilium Tridentinum erat. Cum autem impossibile sit continuam residentiam in duobus locis facere, residentia autem in canonicatu, dignitate et prebenda aut portione requisita censetur, per dispositionem dicti Concilii Tridentini quod etiam ad residendum in parrochiali cogit necessario, consulendum duximus S.D.N.Papam, an canonicus seu dignitatem obtinens aut portionem aut beneficium aliud una cum parrochiali satisfaciat residendo in cathedrali aut collegiata ecclesia.

Publicatum in concilio Prouinciali Tarraconensi die 30 octobris 1564. 
(En el margen izquierdo) Huic decreto dissenserunt Rmi. domini Gerundensis, Ilerdensis et Dertusensis episcopi ac reuerendus abbas Villauertrandi.

\section{Dissensus Rmi. Domini Gerundensis episcopi}

Cum petitio consultationis quae est in memorialibus tradditis super residentia curatorum, ab his qui pluribus beneficiis sunt onerati contraria sit apertis et claris decretis sacri Concilii Generalis Tridentini de eadem residentia disponentibus, et certum sit nos absque huiusmodi consultatione omnibus satifacere posse eadem decreta obseruando et exequendo, ut tenemur tam ex mandato Smi.D.N. Summi Pontificis et Christi Vicarii, quam ex precepto eiusdem sacri et generalis concilii atque etiam seruandi omnium nostrum promissionem et receptionem eiusden sacri generalis concilii die XXIII(I) huius mensis factam, censeo consultationem huiusmodi minime esse faciendam. Non enim praecipiunt sancta et generalis Tridentina Synodus et S.D.N. Summus Pontifex et Christi Vicarius synodis prouincialibus in rebus apertis et ubi non est dubitatio et impossibilitas sanctam Sedem Apostolicam consulere, sed definita et constituta ab eadem sancta synodo deuote recipere et fideliter obseruare et exequi. Quod si cui aliquid obscurius dictum aut statutum videbitur in decretis sancti Concilii obseruandis quod interpretatione egeat, accedat ipse ad locum quem elegit Dominus, idque iuxta forman a sacro generali Concilio Tridentino et sanctissimo D.N.Pont. Summo traditum. Si vero huic prouinciali concilio ista informatione praecedente, quam necessariam iudico, constiterit petitam fuisse consultationem huiusmodi ab his qui plura beneficia habent ob uniuersale bonum et salutem animarum huius prouinciae et non ob commodum particulare petentium, et ideo iustum iudicauerit aliquam consultationem fieri, censeo eorum uota qui pluribus beneficiis sunt onerati, nullatenus admittenda ad tractandum consultationem faciendam esse vel non. Iniquum enim est quem in propria causa iudicem esse. Et haec est mea sententia, quod si aliter fiat, dissentio et peto a vobis notario et scriba huius prouincialis concilii ut in actis eiusdem de verbo ad verbum continuetis et si de facto fiet consultatio in eadem inseratur.

\section{Dissensus Rmi. Domini Ilerdensis episcopi}

Rmus. Dominus episcopus Ilerdensis contradicit petitae consultationi super non residentia quorumcumque curatorum ut in memorialibus petitur, utpote cum sit contra canones apertos sacri Concilii uniuersalis Tridentini de residentia, et cum sine consultatione possimus omnibus 
satisfacere eos seruando, ut tenemur seruare, tum ex mandato S.D.N. papae, tum ex precepto eiusden sacri Concilii, tum etiam seruando omnium nostrum promissionem die XXIIII huius mensis factam. Resolutio vero, salua reuerentia debita Rmo. Domino Archiepiscopo, fieri non debuit acceptis votis siue suffragiis eorum qui habent interesse cum habeant parrochiales ecclesias vel vicarias perpetuas et dignitates et prebendas in ecclesiis cathedralibus vel collegiatis vel abbatias et prioratus cum ipsis ecclesiis vel vicariis. Et cum multi ex eis dederint vel confecerint ipsa memorialia vel adhaeserint iis qui ea dederunt, et sint principales vel procuratores principalium in hoc eodem negotio. Quibus omnibus exclusis fieri debuit propositio et resolutio, eaque de causa hiis omnibus etiam contradicit omni meliori modo, protestans de nullitate et inualiditate omnium actorum et agendorum circa praemissa, petens ut inseratur hoc in actis huius sacri concilii et in consultatione mittenda, si forte mittetur, eidem Smo.D.N.

\section{Dissensus Rmi. Domini Dertusensis episcopi}

Cum benigna omnium vestrum supportatione, Rmi. Domini, patresque Rdi, ad expositam nobis difficultatem de residentia personali, pro parte mea censeo respondendum. Si quidem cum penes me non sit ratio dubitandi quum expositum inueniam in decretis sacri concilii tam circa residentiam praefatam quam circa pluralitatem beneficiorum obtinentes, non video qua ratione consulendus veniat Smus.D.N. in hac parte. Verum si qui inveniunt rationem ambiguitatis, accedant ad locum quem Dominus elegit. Interim tamen ego conscientiae meae consulam sacris sanctionibus inhaerendo tam iuris communis quam eiusdem sacri Concilii, requirens per vos huius sancti Concilii notarium de contentis in hac mea sententia confici instrumentum, inserique in actis praefati concilii.

Intercessio seu dissensus abbatis Villabertrandi ad quaedam decreta synodi prouincialis tarraconensis

Decreto scito a multis patribus in hac sancta synodo Tarraconensi de consulendo S.D.N. an dispensationes concesse canonicis de possidenda simul cum canonicatu parrochiali ecclesia, rata manere debeat post publicatum et receptum sacrum Concilium Tridentinum, ita ut liceat canonice in cathedrali aut collegiata ecclesia residere, parrochialem ecclesiam per vicarium administrare. Intercedit abbas Villaebertrandi atque Synodum Tridentinam in canone de residentia sess. XXIII sic aperte requirere non tantum a superioribus praelatis, sed etiam a curatis 
personalem residentiam, nec permittere cuique abesse a sua parrochiali ecclesia ultra bimestre spatium nisi ex gravi causa, ut nullum reliquerit proposito dubio locum. Grauem enim eiusmodi causam non esse quam excipit synodus officium consiliarii quod episcopo prestat canonicus (quam praecipue dignam dubitandi causam praeferre videntur qui contendunt consulendum esse pontificem) vel inde satis constat quod XV ca. sess.XXIIII, cuius initium est In ecclesiis cathedralibus, statuit subleuari tenuitatem praebendarum in cathedralibus et collegiatis insignibus ecclesiis, uniendo cum praebendis illis, non quidem parrochiales ecclesias aut ulla curata beneficia, sed simplicia dumtaxat, eo nimirum adhibito remedio declarans canonicum curatum grauiorem habere causam residendi in sua parrochiali ecclesia quam in cathedrali aut collegiata, nec sibi placere posthac parrochiales ecclesias aut alia beneficia curata annecti praebendis quod olim in frequenti usu fuit, alioquin idem eidem incommodo adhibuisset remedium.

Intercedit etiam idem abbas illi decreto in hac eadem synodo ab eisdem patribus scito de consulendo eodem Sm.D.N. super ca. XVI sess. XXIIII ob tria quae inde illis videntur existere dubia, quorum primum est: An liceat tertium conferri simplex beneficium ei cui duo non sufficiunt ad vitam honeste sustentandam. Propterea quod cauetur eo cap., ut posthac unum tantum beneficium ecclesiasticum singulis conferatur. Quod quidem si ad vitam eius cui confertur sustentandam non sufficiat, liceat nihilominus aliud simplex beneficium (dummodo utrumque personalem residentiam non requirat) eidem conferri.

Secundum est an in ecclesiis in quibus aut ex consuetudine aut ex decreto cathedralis ecclesiae et episcopi aut vero ex decreto Sedis Apostolicae cauetur ne dignitates aut preposituras aliis quam canonicis eiusden ecclesiae conferantur. An inquam contra hunc canonem sit conferre dignitatem ei qui canonicatum iam habet?

Tertium est an ei qui legitime dispensatus sit ad plures parrochiales ecclesias, rata manere debeat dispensatio. Videturque grauis esse causa dubitandi et digna consultatione propter antinomiam et contrarietatem quae videtur esse inter IIII et V canones sess.VII, quorum altero permitti videntur dispensationes ad plura curata aut incompatibilia iam factae iuxta ca.Innocentii De multa; altero innouatur canon Gregorii X qui incipit Ordinarii locorum, quo prohibentur molestari illi qui euidentes et sufficientes inventi fuerint habere dispensationes. Inter hos inquam canones et ca.XVII sess.XXIIII Cum ecclesiasticus ordo, qui omnino vetat quemque tenere duas parrochiales ecclesias, sed singulos altera contentos esse statuit. Suae vero intercessionis abbas Villaebertrandi has 
breuiter reddit causas. Et quantum ad primum attinet, existimans sanctam synodum non potuisse synodalis styli grauitate et decenti seruata brevitate clarius et dilucidius sensum suum explicare, eum esse ut cuique clerico unum tantum conferatur beneficium et illi cui iam collatum non satis sit, coferendum esse alterum non quodcumque, sed quod cum priore sufficiens sit ad vitam clerici illius honeste sustentandam. Atque ita cum volenti diligenter verba canonis inspicere, constat nullam subesse de primo capite dubitandi causam, constat etiam nec de secundo ullam restare dubitandi rationem. Aut enim legitime vereque unitae sunt dignitates et canonicatus et in his nullus manet scrupulus, aut consuetudo illa et decretum ecclesiae, quam ob causam pro uno habentur, Sedis Apostolicae auctoritate roborata non sunt, ac tunc cum utrumque requirat personalem residentiam, ex eodem canone constat eidem conferri non posse. Denique nec tertium dubium tanti esse videtur, ut de eo consulendum sit Pontifex Maximus. Manifestum est enim XVII ${ }^{\mathrm{m}}$. canonem exceptionem habere et specialem limitationem IIII et $\mathrm{V}$ canonum superius citatorum. Nempe in parrochialibus. ecclesiis, de quibus tam diserte et clare pronuntiat sancta synodus suam sententiam, qua omnino vetat plures simul a quocumque teneri ecclesias, tam multa adhiberet remedia omnibus, quae authores huius dubii obiiciunt difficultatibus, ut verendum sit ne exhalans aliquis fumus de fornace putei abyssi, cuius fit mentio in Apocalypsi, solem nobis obscuret et aerem et has nobis offundat tenebras. Quae omnia Illmi., Rmi. ac Rdi. $\mathrm{DD}$. equi, bonique consulatis ore, vestrumque cum omnium qua decet obseruancia dicta accipiatis.

(Archivo General de Simancas, Patronato Real, 22, 67)

Decreto del concilio provincial de Tarragona para que se consulte al papa sobre algunas dudas en torno a dispensas de beneficios curados Super dispensationibus sustinendis

Dispensationes super pluralitate beneficiorum curatorum et aliorum incompatibilium sustinentur per Concilium Tridentinum expresse in cap.V sess.VII quod incipit: Ordinarii locorum, praesertim autem illae quae ex generali concilio Lateranensi sub Innocentio III in capite De multa de praebendis oriuntur et pro legitimis habentur, videlicet, circa sublimes et literatas personas approbantur in cap.IIII incipienti Quicumque de caetero eiusdem VII sessionis. Licet ergo postea in sess. 
XXIII cap XVII incipienti Cum ecclesiasticus ordo ver . Illi vero mandetur omnibus obtinentibus plures parrochiales ut omnes, praeter unam dimittant, quibuscumque dispensationibus non obstantibus, sub illa generalitate dubium est an comprehendantur dispensationes supradictae, maxime illae quae ex alio concilio generali fomentum habent et per dictum Concilium Tridentinum, ut praefertur in dicto cap. IIII approbantur, quae sub generalitate illorum verborum quibuscumque dispensationibus non obstantibus, non videntur comprehendi, cum speciali mentione videantur egere. Ideo necessario super huiusmodi dubio consulendum censuimus S.D.N. Papam.

Publ. in Conc. Prouinc. Tarrac. 31 octobris 1564.

(En el margen izquierdo) Huic decreto dissenserunt etiam praefati Rmi. D.D. Gerunden., Ilerden. y Dertusen. episcopi ac Rvdus. Abbas Villaeueltrandi.

(Archivo General de Simancas, Patronato Real, 22, 67)

10

31 octubre 1564

Decreto del concilio provincial de Tarragona para que el papa aclare ciertas dudas sobre pluralidad de beneficios.

Super pluralitate beneficiorum

Sanctissime fuit per sacrum Concilium Tridentinum in XXIIII sess., cap. XVII incipienti Cum ecclesiasticus ordo statutum, ut in posterum unum tantum beneficium ecclesiasticum singulis conferatur. Quod quidem, si ad vitam eius cui confertur honeste sustentandum non sufficiat, liceat nihilominus aliud simplex beneficium, dummodo utrumque personalem residentiam non requirat, eidem conferri. Occurrit autem dubitatio, nam per huiusmodi decretum non videtur esse sublata consuetudo rationabilis a iure approbata, quae duo benefficia in eadem ecclesia uni permittat, ut est, si quis dignitatem vel officium vel administrationem seu personatum una cum canonicatu et praebenda vel alio beneficio simplici obtineat. Ex quo in pluribus ecclesiis huius prouincie est statutum antiquissimum et in aliquibus est a Sede Apostolica confirmatum, in aliis vero est ab eadem Sede Apostolica inductum, quod dignitates et officia praesertim praepositurae, non possint nisi per canonicos obtineri. Quod inter alias rationes hac praecipua inductum videtur, quod cum praebendae sint ita tenues ut ex illlis commode quis sustentari non possit, et dignitates regulariter in ecclesiis 
cathedralibus nullum ministerium exerceant, inconueniens non videtur, ut quis illa simul obtineat.

Insuper ex generali consuetudine beneficia simplicia non requirunt residentiam, qua ratione duo, si unum sufficiens non est, per Concilium Tridentinum permittuntur; eadem ratione etiam tria et quatuor et plura simplicia vel cum eis unum curatum uni conferri posse videntur. Et quia dubitari posset an facultas prouidendi de duobus possit extendi ad plura alia simplicia, etiam si inter ea sit unum curatum, ideo merito super huiusmodi dubium prouinciale concilium S.D.N. Papam consulendum censuit.

Praeterea, quia quamvis in concilio Lateranensi per sacrosanctam Synodum Tridentinam innouatum sanctissime sacratum fuisset, nemini liceat duas parrochiales ecclesias obtinere, tamen per Alexandrum Tertium in decretali Eam te, De aetate et qualitate declaratum fuit, id non intelligi, quando sunt ita tenues in substantia quod proprios sacerdotes non possint conuenienter alere, quarum copia maxima reperitur in hac prouincia Tarraconensi. Ad quam tenuitatem sacrum Concilium Tridentinum prouide respiciens in XXI sess. cap. V incipienti Ut etiam ecclesiarum status dat licentiam ordinariis faciendi uniones perpetuas quarumcumque ecclesiarum parrochialium propter earum paupertatem. Et quia uniones huiusmodi in hac prouincia cum magna difficultate et non sine querella plurimorum fieri possunt, ideo concilium prouinciale S.D.N. Pape supplicandum decreuit, ut qua ratione datur facultas ordinariis ut duas ecclesias parrochiales tenues uni conferri possint, declarato, si Sanctitati suae videbitur, valore ipsarum parrochialium ut sic videatur usque ad quam summam possit tenuitas fructuum considerari.

Publicatum in conc. Prouin. Tarraco. 31 octobris 1564.

(En el margen izquierdo) Huic deccreto etiam dissenserunt praefati Rmi. Domini Gerund., Ilerden. et Dertusen. episcopi ac Rvdus. Abbas Villaebertrandi.

(Archivo General de Simancas, Patronato Real, 22, 67) 
Decreto del concilio provincial de Tarragona solicitando del papa que los que han resignado beneficios en manos de los obispos reciban una pensión como si los hubiesen renunciado en manos del Sumo Pontífice.

Pro resignantibus beneficia in oboedientiam sacrosancti Concilii Tridentini.

Cognouit prouide sacra Tridentina Synodus nimium dispendium passuros eos qui plures parrochiales ecclesias obtinentes, omnes praeter unam iuxta cap. XVII quod incipit Ecclesiasticus ordo sess. XXIIII infra sex menses dimittere cogebantur. Et propterea in fine eiusdem capituli piissima eorum viscera patres illi prudentissimi aperientes dixerunt optare resignantium necessitatibus commoda aliqua ratione prout Summo Pontifici videretur, provideri. Nulla autem commodior et facilior visa est quam reservando pensionem in favorem resignantis super fructibus parrochialis resignatae de consensu resignatarii. Quod plane, ut intellexit haec provincialis synodus, obseruatum est in resignationibus in Curia Romana et in manibus Romani Pontificis factis. Verum quia propter temporis breuitatem plurimi tarde habentes noticiam declarationis S.D.N. Papae, quod dicti sex menses a kalendis maii inciperent currere, non potuerunt debitas diligentias facere ut resignarent in Curia. Et propterea ut euitarent poenas a sacro concilio impositas, coacti sunt in manibus ordinariorum parrochiales quas obtinebant resignare. Supplicandum videtur eidem S.D.N., ut etiam ex causa resignationis in manibus ordinariorum factae, quibus resignarunt de consensu eorum qui de parrochialibus per eosdem ordinarios prouisi fuerunt, pensiones reservare dignetur, perinde ac si in manibus eiusdem Summi Pontificis resignationes factae fuissent.

Public. in conc. prouin. Tarraco. 2 nouembris 1564.

(Archivo General de Simancas, Patronato Real, 22, 67)

Los monjes de la Orden de San Benito, llamados negros, desde tiempo inmemorial llevan una vida algún tanto laxa y pretenden que no se les puede imponer la vida común, pero dudan si su género de vida se ajusta o no a los decretos tridentinos. Lo mismo sucede con la rama femenina de la Orden. Sobre ello el concilio provincial ha resuelto consultar al papa y pedirle que en adelante no se encomienden las abadias ni los 
oficios claustrales que han causado la ruina de los edificios y el colapso de los refectorios, dormitorios y otras oficinas.

Dubia et difficultates quae tangunt monachos. nigros Ordinis Sancti Benedicti huius Tarraconensis prouinciae.

In Prouinciis Tarraconensi ac Cesaraugustae, quae pro una reputantur, monachi Ordinis Sancti Benedicti, qui nigri uocantur, regulam dicti Sancti Benedicti secundum constitutiones felicis recordationis Papae Benedicti XII, ac constitutiones prouinciales profitentur. Viuunt enim isto modo, videlicet, quod quolibet triennio capitula prouincialia celebrant, ibique Praesidentes et uisitatores eligunt, ac prouinciales constitutiones ad bonum statum sui Ordinis conseruandum statuunt et unoquoque triennio sua monsateria visitant, comedunt bini aut terni in suis cellis intra claustra monasterii constitutis, daturque omnibus monachis per abbatem aut per officiales ad hoc deputatos portio panis et vini et aliarum rerum ad victum necessariarum. Vestiarium etiam omnibus praebetur per camerarium qui singulis annis quandam summam modicam soluit, ex qua et anniuersariis et aliis christifidelium et consanguineorum largitionibus vestitum sibi monachi comparant atque aliquam superlectilem ac etiam pecuniam in suis cellis cum scientia et permissu superiorum habent, de quibus omnibus per scripturam inuentarium continentem aut per clauium traditionem superiori semel in anno rationem reddunt. Quem modum ab immemoriabili tempore citra et supra obseruarunt, neque alium in suo probationis anno experimento didiscerunt. Et propterea ad strictum modum viuendi praetendunt se non teneri. Dubitant an satisfaciant monachi praedicti eo modo viuendi decretis sacri Concilii Tridentini loquentibus de reformatione regularium. Et idem dubium quod ad praefatum modum viuendi oritur quoad moniales dicti Ordinis quae nunc ex parcissima portione quam ex monasterio omnes percipiunt et subuentionem parentum vel aliorum consanguineorum in earum cellis vitam pretendunt ducere communem. Et si ad aliam vitam communem compellerentur, cessarent praedictae subuentiones, consideratisque praedictis et tenuitate redituum monasteriorum, alia communis vita non videtur eis iniungenda. Super quibus haec sacra synodus prouincialis S.D.N. Papam consulendum duxit.

Etenim aliqua monasteria commendata, culpa commendatariorum, in eorum edificiis pene collapsa reperiantur et pluribus monasteriis officia claustralia quae ex primaeua institutione ad nutum abbatis seu superioris mobilia erant, et illa sacrum Concilium Tridentinum in cap. II de Regularibus ad eandem manualiter reducere videtur, quaedam ad vitam 
clericorum secularium per Sedem Apostolicam fuerunt hactenus commendata, alia vero pluribus monachis aliorum monasteriorum per eandem Sedem Apostolicam perpetuo collata existunt. Quo fit ut constitutio papae Benedicti XII cap. incipienti Rursus quia in ecclesiis, qua praecipitur ut abbates ter in anno compellant obtinentes dicta officia seu administrationes ad reddendum rationem suarum administrationum et quidquid supererit in necessitatem aliorum monachorum vel in alios usus monasterii necessarios, prout abbati videbitur conuenire, conuertatur, obseruari minime potest, nec abbates potentes sunt ad compellendum obtinentes dicta officia ex prouisione seu gratia Sedis Apostolicae soluunt et supportant debita et necessaria onera dictorum officiorum, immo cum dicatur regulam reseruatoriam octo mensium officia claustralia praedicta comprehendere, remanent fere spoliati abbates seu alii superiores facultate praedicta officia seu administrationes monachis suorum monasteriorum committendi seu assignandi, quod est in causa, quominus debita dictorum monasteriorum reformatio fiat, et dormitoria ac refectoria, caeteraeque officinae quae hodie in aliquibus monasteriis penitus collapsae sunt, et in ruinam propemodum deuenerunt, debite reparentur. Et idem contingit prioratibus non conuentualibus a monasteriis dicti Ordinis dependentibus, cum sit eadem ratio si clericis secularibus commendentur vel monachis aliorum monasteriorum conferantur.

Propterea nomine huius sacrae synodi prouincialis supplicandum videtur S.D.N. papae, quatenus dignetur Sanctitas sua declarare dicta officia claustralia et prioratus non conuentuales sub regula reseruatoria praedicta non comprehendi nec quovis modo generaliter vel spetialiter reseruata seu affecta dici posse, sed quocumque modo, etiam si per cessationem commendae illa nunc obtinentium seu alias ut prius vacent, per abbates monachis suorum monasteriorum ad eorum nutum committi seu asssignari posse.

Publicat. in conc. Prouinciali Tarraconensi 6 nouembri 1564.

(Archivo General de Simancas, P.R., 22, 67) 
A Gonzalo Pérez. El Arzobispo de Tarragona a VII de noviembre de 1564. Al ilustre y muy magnifico señor el secretario Gonzalo Pérez, mi señor, del Consejo de su Magd., etc.

Ilustre y magnífico señor.- La de Vm. reçebí, respuesta a la mía. Esta mañana reçebí la de su Magestad y la que venía para la congregación se leyó en ella, y en la misma hora de mí mesmo prorrogué la prouincia para quince días después de Pascua, con reseruatión que la pudiese antes çelebrar o mudar el lugar dónde y quándo mes paresçiesse, porque su Magestad entienda y sepa que nos aiuntaremos siempre que fuere seruido y que nos dexaremos de congregar, si en ello fuere deseruido, de modo que la suspensión y prorrogatión está hecha de manera que su Magestad puede della disponer lo que más seruido fuere.

Yo conuoqué esta prouincia contra mi uoluntad, aunque no pude dexar de conuocarla porque vi que su Magestad había recebido y aceptado el Concilio Tridentino y que con tanta furia, con diuersos pregones y atabales y trompetas se hauía mandado, no sólo a sus súbditos, pero a todos los prelados que todos hiciessen lo mesmo. Y también, porque ví que entre los obispos y capítulos y otros eclesiásticos hauía grande discordia y temía de un grande scándalo en Cathalunia. Por sedarlo, conuenia que yo celebrasse ei concilio y congregasse para ello la prouinçia. No di a su Magestad aviso dello, porque me parescía era superfluo, viendo lo que nos hauía mandado y ansí en todo he sido y soy fuera de culpa, y si culpa ay, aquélla tienen los que mal le han aconsejado. Que deuían primero muy bien mirar en qué cosas le preiudicaua el Concilio, antes de reçebirlo o a lo menos antes de mandar lo que mandó por todos sus reynos, que lo aceptassen y cumpliessen todos sus súbditos.

También veo que por via del visorey me ha scrito y mandado que por la via que mejor me paresciere, con toda disimulatión prorrogue el dicho conçilio, y estoy admirado cómo no me lo mandó en la primera letra que me embió con mi criado. Porque en esta materia de Conçilios prouinciales tiene tan gran poder el Arçobispo, que a sola su voluntad, sin parescer y approbación del Conçilio, immo ipso contradicente, puede extinguirlo y prorrogarlo, y si en este día yo no houiere venido a la congregatión, houiera del todo expirado, ansí que si su Magestad por la otra me lo mandara, luego fuera hecho. Ello está bien asentado, pues queda su Magestad seruido; y se ha hecho de mi propio motivo, tomando ocasión y causa de lo que su Magestad en común nos ha scrito. 
Lo que aquí se ha hecho, fue acceptar y reçebir el Conçilio. Embío a su Magestad essa acceptatión y prorrogatión deste nuestro Conçilio authéntica, porque sepan los otros metropolitanos la forma que han de tener en reçebir y acceptar el general Concilio. Vm. por merced la vea y mande emendarla, que siempre hallará alguna falta. Ninguna otra cosa se ha hecho que ha tenido effecto.

Esto de poner personas para que examinen las que su Magestad nombrará para las iglesias cathedrales es de muy grande importancia y de muy grande periudicio suyo. Perdónelo Dios a los que lo hizieron. Que paresçe que ya que no le pudieron quitar el patronazgo que es suyo, y con tan justo título, por hauer cobrado de manos de infieles sus reynos, han procurado quitárselo por indirecto. Conuiene que en esto se mire mucho. Y pues Vm. por lo que a su Magestad scriuo entenderá lo demás y todo lo que se ha hecho, no le seré más molesto.

Beso las manos de $\mathrm{Vm}$. por lo que me scriue de la consulta que piensa que se terná en Sogovia y que huelga de se hallar allí por me hacer merced señaládome estaría bien en Carthagena, aunque está muy dismembrada. Ya sé yo que Vm. me dessea hacer merçedes y tiene muy grande razón, que con toda verdad no tiene seruidor que con más voluntad que yo le desee seruir, como lo verá por obra siempre que mandará seruirse de mi persona, que no le seré jamás ingrato. En hombre que está tan affligido como yo lo soy estado y estoy en esta iglesia, qualquiera otra le conuendrá más que ella. Que aunque jamás he sido creído, no me dexe Dios gozar della ni de otra, si llega a valer diez mil ducados. Bien que vale nueve mil y quinientos, y haze cinco mil ducados de pensiones y cargos, sin los mil y quinientos que agora me piden de nuevo. Vea Vm. cómo puede biuir un arçobispo, que está siempre fuera de su diócesis, siruiendo a su Magestad en una cosa o en otra, donde ha de tener casa doblada. Carthagena es muy buena cosa y iunto a mi Collegio y casa. Pero, como puesto que soy gallego de parte de padre, sea de parte de madre valenciano, natural de la ciudad de Origuela, la qual ciudad siempre ha tenido grandes differentias con la ciudad de Murcia, donde está la yglesia cathedral de Cartajena, y como yo sea muy emparentado en aquella ciudad, que casi no hay cauallero que no sea mi deudo, han tenido siempre los de Murcia de mí y de mis deudos muy grande sospecha $\mathrm{y}$, como agora estén indignados en hauerles tanto dismembrado su prelatura y dado a Origuela y que sobre ello vean que les dan el prelado de la mesma ciudad y tierra, darse han a todos los demonios, por donde tengo por cierto que ni ellos ni yo quedaremos quietos ni descansados. 
Lo que yo querría y más conuendría al seruicio de su Magestad y descanso mío es que sobre Málaga o sobre qualquier otra pieza se me hiziese merced de alguna pensión para descargar esta mi carga. Porque veo y es notorio que tiene necessidad de mi en Cathalunia como del pan que come, y esto sin soberuia alguna, para muchas cosas que se offresçen de cada día. Y si esto no fuesse possible, me hiziesse merced antes de Málaga que de Cartajena. Pero dexar el título de arçobispo no conuendría sin tener otro título de patriarcha que se da como un obispado de gracia. Vm. es señor mío y sé que tiene voluntad de me hazer mercedes, como tengo dicho, en manos de Vm. pongo a mí y quanto tengo, que soy muy cierto lo hará conmigo, como lo haría yo en su seruicio.

Guarde nuestro Señor la ilustre y muy magnífica persona de Vm. y con augmento de stado conserue. Desta su ciudad de Tarragona, a siete de nouiembre 1564 .

(Con otra letra) Besa las manos a vuestra merced su más cierto seruidor

el Arçobispo de Tarragona.

(Archivo General de Simancas, P. R., 22, 15, original)

14

Dubdas mouidas por los perlados de Catalunia después de hecha la prorrogación del Synodo prouincial para en Catalunia. Sin año.

Después de prorrogado el prouincial concilio de Tarragona, estando allá todos ayuntados, se an presentado estos dubios. Ay necessidad que su Magcstad mande dcclarar lo que más scrá scruido sc haga, y V. Magestad mande embiar al arçobispo la respuesta para que pueda avisar a los obispos de lo que pueden y deben hazer en esta causa.

Primo. En este Concilio Prouincial a nombrado cada obispo ciertas personas para juhezes delegados, a quien el papa a de cometer las causas que de la misma diócesis fueren a Roma. Dúdase si enviarán allá la nómina de los dichos juhezes, la qual según el Tridentino Concilio después se an de enbiar a Roma y no se enbiando, conoscerán allá las causas y no vernán en Espania. Dúdase, porque si esto se enbía, parescerá que a causa de hazer juhizios cómo se enbía una causa y no otra.

Lo segundo, manda el Concilio General que se hagan examinadores en concilio synodal para examinar los que se an de proveher en rectores 
y otros beneficios curados. Es la duda si para estas y otras cosas conuocarán los obispos sus diocesanos synodos o si se dexarán de conuocar ahora y su Magestad lo mande. Ay grande inconueniente si no se conuocan y no se eligen examinadores en ellos, porque estarán las rectorías que vacaren, vaquas, que no las podrán proveher los obispos, porque no se pueden proveher sin los dichos examinadores.

Lo tercero, manda el dicho general Concilio que de aquí andelante no aya en el sacramento del baptismo y de la confirmatión sino dos padrinos. Ay duda si se publicará y mandará esto. $\mathrm{Y}$ también lo del matrimonio clandestino por las diócesis, que está todo prohibido y anullado.

Lo quarto, si entretanto que la dicha prorrogación durase, mandarán los obispos en sus diócesis se executen y guarden los decretos de la residentia y las clausuras y reformationes de los monasterios. $\mathrm{O}$ si se sobrecesrá sobre ello.

(Archivo General de Simancas, P.R., 22, 68 I)

Dubdas mouidas en el Concilio prouincial de Tarragona, que son generales para toda España.

Por los congregados del Conçilio Prouinçial de Tarragona se han mouido las dudas siguientes que se pueden mouer en otros conçilios prouinciales.

Primero. Que en algunas Yglesias Cathedrales hay ordinationes apostólicas o reformationes hechas por los papas o constitutiones por ellos confirmadas que disponen y mandan que las dignidades $y$ preposituras se prouean y den a los canónigos de las mesmas yglesias y no a otros. Y porque agora en el Tridentino Conçilio se manda que al que tiene un beneficio, no se le dé otro, sino en çierta forma, es la duda si se incluyen los dichos canónigos que no puedan tener las dichas dignidades, pabordrías o beneficios, que por conçessiones apostólicas se han de conferir a ellos mesmos y no a otros.

Secundo. El dicho Conçilio Tridentino generalmente statuye y manda que todos los rectores y curas de ánimas hayan de hazer personal residentia. Es la duda, si en esto son comprehendidos los canónigos de yglesias cathedrales y otras semejantes personas eclesiásticas que tienen rectorías y otras yglesias curadas. Porque, como sean obligados a hazer residentia en su cathedral yglesia, paresçe que no son obligados a la 
hazer en otra. O si serán obligados a la hazer en sola la cura teniéndose el canonicato o si son obligados a dexar la una o la otra.

Tertio. Muchos abbadiados y conuentos del orden de S. Benito y de $\mathrm{S}$. Agustín en Cathalunia, Aragón y Nauarra tienen quasi todos los offiçios de camarería, infermería y otras dignidades de sus casas en poder de clérigos seculares provehidos por la Sede Apostólica y ansí están estas rentas y offiçios fuera de la casa, y tienen los que quedan y residen en el conuento su común vida. Dizen que para hazer y cumplir lo que el sacro Conçilio les manda, no se puede bien hazer, que no tornen a casa las rentas y offiçios della, y que de aquí aldelante no se prouean a personas seculares los tales offiçios.

(Archivo General de Simancas, P.R., 22, 68, II)

16

c. 3 octubre 1565

Minuta de carta que se embió para firmar del rey para el Arzobispo de Tarragona en respuesta de lo que escriue en las cosas del Concilio Prouincial.

Al arçobispo de Tarragona.- El Rey-. Muy reuerendo en Christo padre arçobispo, del nuestro Consejo. Vuestras cartas de XIIII ${ }^{\circ}$ y

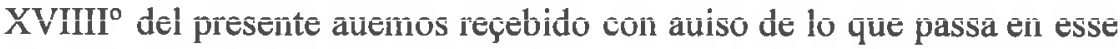
Concilio Prouincial, lo qual agradeçemos mucho y assí os encargamos mucho que con el mismo cuidado y diligencia que hasta aquí lo continuéis, como de vos confiamos, procurándolo de guiar y encaminar según las intructiones y aduertimientos que se os han mostrado, que assí respondemos al conde lo haga en todo y particularmente en lo que nos ha consultado sobre los apuntamientos que se trataron en Tarragona estando allí la prouincia, como se entiende que ay algunos que quieren referirse y estar a lo que estaba apuntado allí, porque como aquello fue tratado con mucha celeridad y sin auer persona que por nos asistiesse, y no auiendo auido execuçión dello ni auer sido publicado, sería bien que de nuebo se voluiesse a tratar con más discusión y acuerdo atendiendo vos y procurando, según assi mesmo lo escreuimos al conde de Aytona, que sea de manera que por las instructiones se ha aduertido teniendo muy grande miramiento en encaminar y guiarlo todo según la intinción que por aquéllas tenéis entendido y sin salir dellas, que al nuestro lugarteniente escriuimos que os ayude y fauorezca en todo lo que fuere necesario y si el negocio requiere, que consulte algunas cosas con los de la Rota pidiéndoselo vos o el conde, que assí lo haga y de 
todo lo que succediere, nos daréis particular auiso, que en ello nos daréis mucho contentamiento.

Quanto a lo que escriuís a Mr. Serra, ya os respondimos sobre ello lo que nos pareció y de lo que ahora nos auéis scripto con dichas cartas, tendremos la consideraçión que es razón se tenga y se verá lo que más conuenga. Datum.

(Archivo General de Simancas, P. R., 22, 14, III)

Como la mayor parte de las monjas de Cataluña pretenden que no se les puede imponer una clausura que no han profesado, ni les es posible, por su pobreza, reformar los edificios, el concilio pregunta al papa qué debe hacerse. Votan en contra los obispos de Lérida, Elna y el abad de Villabertrán.

\section{Super reformatione monialium}

Monasteria sanctimonialium huius prouinciae Tarraconensis, praeter aliqua Ordinis Sancti Francisci de Obseruantia et alia sub cura fratrum Ordinis Praedicatorum, in quibus perpetua clausura exactissime seruatur, nunquam hucusque perpetuam et arctam clausuram receperunt. Sunt autem aliqua dictorum monasteriorum ordinis Sancti Benedicti et Cisterciensis, alia Sancti Augustini et Sancti Ioannis Hierosolymitani, sed in eis semper solitum fuit ex licentia abbatissae aut priorissae etiam secularibus personis, praecipue autem ipsarum sanctimonialium parentibus et consanguineis non suspectis, claustra monasteriorum ingredi et ipsis sanctimonialibus per eandem abbatissam aut priorissam ex iusta causa eis bene visa licentia exeundi a monasteriis ad tempus tamen limitatum et ad honestum hactenus concessa fuit. Et tam in visitationibus superiorum quam in quibusdam constitutionibus in capitulis prouincialibus editis, tum etiam in aliquibus monasteriis per litteras appostolicas antiquissimas datus est ordo ipsis sanctimonialibus quem obseruare debeant cum a monasterio de ipsius abbatissae seu priorisse licentia ex iusta arbitraria causa exeunt. Quapropter sanctimoniales dictorum monasteriorum videntes formam et modum viuendi ab antiquo in dictis monasteriis obseruatum, quodque ipsae nec expresse vouerunt clausuram perpetuam astrictam nec illam spontaneae suscipere volunt, cum per earum regulam nec morem hactenus obseruatum non sit eis indicta, pretendunt non posse compelli ad dictam perpetuam 
clausuram arctiorem iuxta constitutionem Bonifacii VIII quae incipit Periculoso, per decretum V, sess.XXV de regularibus sacrosancti Concilii Tridentini innouatam.

(Al margen izquierdo) Huic decreto dissenserunt Rmi. Domini Ilerdensis et Elnensis episcopi ac Rdus. abbas Villaebeltrandi.

Dubitant etiam superiores dictorum monasteriorum, quae subiiciuntur eorum capitulis prouincialibus aut generalibus, cum dicta monasteria eis subiecta reformare et in illis regularis disciplina vigeat, praecipue vero religiosa castitas obseruetur, curare et ipsas sanctimoniales ad praemissa iuris remediis compellere parati existant, an liceat episcopis vigore dicti decreti $\mathrm{V}$ in praefatas sanctimoniales seu eorum monasteria vel alias personas claustra dictorum monasteriorum ingredi volentes absque eorum licentia seu contra dictas sanctimoniales a dictis monasteriis exeuntes absque dictorum episcoporum approbatione, aliquam iurisdictionem exercere iuxta tenorem praefati decreti $\mathrm{V}$.

Difficultas insuper oritur cum omnia fere monasteria huius prouinciae habeant redditus tenues, ex quibus absque piis parentum et aliarum consanguineorum dictarum sanctimonialium subuentionibus praefatae sanctimoniales sustentari seu ali non possunt. Ut etiam dicta monasteria ad dictam perpetuam clausuram arctiorem reducantur, necessarium erit vel antiquas officinas aliquatenus collapsas reficere vel in aliquibus monasteriis de nouo eas construere, et in omnibus monasteriis alia facere sine quibus dicta astrictior clausura obseruari non potest. Quae fieri nequeunt absque maximis expensis, quas praefata monasteria sustinere non possunt, cum redditus illorum ad vitam sanctimonialium parcissime sustentandam non sufficiant. Quae omnia rem difficilem reddunt, ut praefatis sanctimonialibus perpetua et arcta clausura indicatur. Supplicat praeterea sanctum prouinciale concilium l'arraconense Sanctissimo Domino nostro papae ut quid circa praemissa agendum sit Sanctitas sua declarare dignetur.

Publicatum in concilio Prouinciale Tarraconensi Barchinoae celebrato 5 octobris 1565 .

(Archivo General de Simancas, Patronato Real, 22, 67) 
Advertencias a los informes de los condes de Morata y Aytona relativos a los Concilios Provinciales de Aragón y Cataluña.

Simancas, Patronato Real 22, 26 (I borrador) (II puesta en limpio)

Lo que se ofresce que aduertir en lo que scriuen los Condes de Morata y Aytona tocante a los Concilios Prouinciales de Aragón y Catalunia.

\section{En lo de Aragón}

Que la protestación que algunos hicieron en el Concilio por el nombre / de protestación y por la ocasión en que se hizo consiguientemente / a la aceptación del Concilio, y por unas palabras que se añadieron / en ella de vsar del remedio y derecho que les compitiesse, se / pudiera bien escusar y no puede dexar de ser de inconueniente, / aunque la substancia de lo contenido en la dicha protestación, / que fue reseruar el derecho de consultar (lo qual de suyo se enten/día y ni suspende la execución ni condiciona la aceptación), / no era de mucha consideración./

El insistir en que se aparten y desistan desta protestación y hazer / sobre ello esfuerço, podría ser de inconueniente, porque se daría / occasión a dezir, como es cierto que dirán, que se quiere quitar / el recurso y la consulta a su Santidad y / esto tomaríase muy mal por su Sanctidad.

Si se pudiese encaminar que los mismos que hizieron la protesta/ción, la declarasen diziendo que por ella no entendían ni / auían entendido poner condición en la aceptación del / Concilio ni que se suspenda la execución, sería muy bueno y satisfaría a todo; mas verisimilmente esto será difficultoso / y aun podría ser de inconueniente tratarlo con ellos, porque no / se les diesse occasión de passarlo adelante y declarar lo contrario, / que sería ponerlo en peor estado./ (f. 1v).

Paresce que el Arçobispo de Çaragoça, los Prelados y los demás / que no protestaron, podrían dezir y declarar que, pues en la dicha / protestación no se reserua más del derecho de consultar / a su Sanctidad y que esto en lo que será necessario, se entiende assí, / y siempre se podrá hazer, y que por la tal reseruación ni se condicio/na la aceptación ni se suspende la execución, que se deue, sin / embargo della proceder adelante y que esto se ponga assí por / aucto, con lo que se podrá muy bien proceder sin inconueniente./ Y quando se representasse del estado en que los negocios allá están, / que en esto le ay, es menor el dexarlo 
assí, que no hacer insistencia / con mucha contradicción por lo que está apuntado./

Quanto a la carta del Concilio para su Sanctidad sobre lo del conyugio, / aunque en ella se apuntan muy buenas y sanctas consideraciones, / en el modo y palabras que se ponen y términos de que se vsa, / ay que templar y mudar, demás que no paresce que se lleua en / ella ni se satisfaze al fin que en esto se tiene; será bien esperar / las otras cartas que han de venir de los demás Concilios y, vistas / las vnas y las otras, mandará su Majestad aduertir a todos de lo que / pareciere conuenir para endereçar que la substancia y fin sea / vno en todas, aunque en la forma y tenor diffieran. Esto se dize / para acá, que al Conde de Morata bastará auisarle del recibo de / la dicha carta y que les diga que su Majestad les mendará aduertir / con otro de lo que le paresciere./

En lo que el dicho Conde consulta si se dará prissa o yrá despacio / el Concilio, paresce que por agora en los primeros principios hasta / ver cómo el negocio se encamina y lo que se descubre, será bien / proceder despacio, que después se podrá vsar de mayor diligencia / y breuedad en el tratar de los negocios./ (f. 2 r)

\section{En lo de Catalunia}

El fundamento que se toma por los del Concilio que, lo que agora / se haze, es continuación, presupuesto el principio que en él / huuo, no paresce que se deue buenamente negar; mas con todo eso, / si se pudiesse buenamente encaminar que los actos primeros / de la aceptación del Concilio y de lo demás a título de satisfazer / a los que desto dudassen, se tornassen a hazer y fuesse desde / agora como principio por enflaquescer el fundamento que toman / los que quieren affirmarse en lo hecho paresce que sería conue/niente y, en caso que esto no se pueda encaminar o no parezca / conuenir, en lo que toca a los cabos que están apuntados para / consultarse, aunque sea continuación, paresce que pueden muy / bien tratarse dellos de nueuo, pues no huuo, a lo que acá paresce / por los auctos, sobre esto decretación ni determinación del Concilio, / sino que sólo es memorial y apuntamiento dado para este effecto / de consultar $y$, aunque hubiera auido decreto o determinación / del Concilio, no siendo para determinar las cosas y cabos allí / contenidos, sino sólo para consulta, no impide tornarse a tratar / ni el reformarlo y mudarlo, si les paresce, y la causa que se da / y el título que se toma para que no se torne a tratar, de auerse / hecho assí con tan poca discussión y con tanta celeridad y de / no auer interuenido ni 
assistido persona por su Magestad, paresce / que es muy sufficiente y, según los cabos son, importa mucho que / no se dé aquello por resuelto, y teniendo el Arçobispo de Tarra/gona, como tiene, tanta jurisdictión y auctoridad en este negocio del Concilio, paresce que podrá bien ordenarlo y / endereçarlo assí.

No se pudiendo salir con esto de que se torne a tratar o ya que se / tratase, affirmándose en lo que han dicho, paresce que será muy importante que esta consulta venga a mano de su Magestad // (f. $2 v$ ) y que por su medio se encamine conforme a lo contenido en el / memorial de aduertimientos, y esto en qualquier estado / que el negocio tenga, paresce que aurá lugar.

Vna cosa pretenden los que han dado los dichos apuntamientos / para consultar a su Sanctidad, en que ni tienen razón ni se deue / en ninguna manera permitir, y es que la dicha consulta suspenda / la execución y que, en el entretanto, se ha de parar en ella. / Hase de mirar mucho cómo esto se trata y que, en lo que toca a la / execución, ni se ha de parar en el effecto ni se ha de dexar/de tratar de todos los dichos cabos y puntos para lo que toca / al entretanto.

A los otros puntos de las cartas de los dichos condes ordenará / el Consejo la respuesta que vieren que conuiene.

El concilio tarraconense pide al papa que quite las dificultades que los canónigos regulares de San Agustín encuentran en los decretos tridentinos.

Commonitorium difficultatum, quas abbates, priores et praepositi canonicorum regularium Ordinis Sancti Augustini sentiunt in obseruandis decretis sacri concilii oecumenici Tridentini de regularibus. Quamobrem, quia solus S.D.N. eas potest tollere, supplicant ut nomine totius concilii Tarraconensis sua Sanctitas super his consulatur.

Primum hoc discernere diffficile est an decreta sacri Concilii Tridentini de regularibus sess.XXV omnes cuiuscumque ordinis regulares comprehendat an vero illos dumtaxat quos, ut statuit primus canon, superiores ad horum decretorum obseruationem omni adhibita cura et diligentia tam in capitulis generalibus et prouincialibus quam in eorum visitationibus possint cogere. Iam enim cum in Hispania Tarraconensi canonici regulares ante hominum memoriam nulla talia soliti sint habere capitula, nec illis habenda posthac a sancta synodo iniuncta sint, hisce 
synodus unum atque adeo, si opus sit, duo beneficia, eidemque beneficiorum illorum bona mobilia et immobilia, puta agros, domos et alia id genus stabilia, et inde prouenientes redditus ad usum et administrationem aut commendam saltem nomine conuentus tenenda et possidenda contendit, cum haec adhaereant beneficio ut corpus animae in animali. Contra vero vetat sancta synodus II canone iam saepe citato, ne quisquam regularium bona mobilia vel immobilia etiam nomine conuentus possideat aut teneat. Item et XVII cano. sess.XXIIII vult subleuari inopia regularium de bonis ipsis regularibus appropriatis, nempe de bonis beneficiorum illis conferendorum. Tertius vero canon de regularibus subleuari vult de bonis communibus ipsis regularibus nimirum de bonis monasteriorum et de consuetis eleemosynis, ideoque statuit ne maior numerus in monasteriis recipiatur quam qui commode ex bonis illius ali possit.

Publicatum in concilio prouinciali Tarraconensi Barcinone celebrati die 11 octobris 1565. (AGS, P.R, 22,67).

El Concilio provincial de Tarragona nombra una comisión que concrete los puntos que han de consultarse al papa sobre la residencia de inferiores.

Die veneris duodecima mensis octobris anno a Natiuitate Domini millesimo quingentesimo sexagesimo quinto, hora secunda post meridiem ipsius diei, ad quas diem et horam huiusmodi Concilium Prouinciale Tarraconense fuit prorrogatum, post pulsationem campanae maioris dictae ecclesiae Barcinone in domo capitulari eiusdem ad continuationem et celebrationem dicti Prouincialis Concilii, existente ibidem et assistente pro S.C.R. Maiestate dicto multum illustrissimo domino comite de Aytona, conuenerunt et praesentes fuerunt sequentes: Illmus. ac Rmus dominus archiepiscopus

Rmus. dominus episcopus Ilerdensis

Rmus. dominus episcopus Elnensis

Rmus. dominus episcopus Barcinonensis

Rmus. dominus episcopus Urgellensis

Rmus. dominus episcopus Vicensis

Rdus. abbas de Stagno

Rdus. abbas monasterii Sancti Petri de Gallicantu

Rdus. abbas monasterii Sanci Cucuphatis Vallensis 
Rdus, abbas monasterii Riuipullensis

Rdus. abbas monasterii Populeti

Rdus. abbas monasterii de Bisuldino

Rdus. abbas monasterii Sancti Benedicti de Bagiis

Rdus. abbas monasterii beate Marie de Monteserrato

Rdus. abbas monasterii de Villabertrando

Rdus. abbas monasterii de la Vaix

Rdus. abbas monasterii Sancti Laurentii de Monte

Rdus. Raphael Ioannes Gili, canonicus et sindicus Rdi. capituli ecclesie Tarraconensis

Rdus. Petrus Paulus Çaragoça, canonicus et sindicus Rdi. capituli ecclesiae Barcinonensis

Rdus. Franciscus de Castellbell, canonicus et sindicus Rdi. capituli ecclesie Ilerdensis

Rdus. Petrus Trauer, canonicus et sindicus Rdi. Capituli ecclesiae Gerundensis

Rdus. Raphael Domenec, canonicus et sindicus Rdi. capituli eccclesie Vicensis

Rdus. Iacobus Ceruero, archidiaconus de Corbera, canonicus et sindicus Rdi. capituli ecclesiae Dertusensis

Rdus. Petrus Spin, archidiaconus maior, canonicus et sindicus Rdi. capituli ecclesiae Urgellensis

Rdus. Michael de Homs, abbas de Arles, canonicus et sacrista ac sindicus Rdi. capituli ecclesiae Elnensis

Rdus. Iacobus Moragues, procurator Rdi. Abbatis de Stagno et prioris Sancte Anne Barcinone

Rdus. frater Franciscus de Tor de Laguna, procurator Rdi. Abbatis monasterii Beate Marie de Monteserrato

Rdus. frater Raymundus Sopena, sindicus et procurator monasterii de la $O$, sede abbatiali vaccante.

Rdus. frater Laurentius Ysalguer, procurator Rdi. abbatis monasterii Sancti Ioannis de Abbatissis

Rdus. frater Ioannes de Gusman, procurator et oeconomus monasterii Sancti Victoriani, sede abbatiali vaccante.

Quibus omnibus congregatis Super materia residentiae inferiorum, habito prius super ea longiori tractatu, fuit conclusum per dictum illustrissimum ac reverendissimum archiepiscopum ac per dictum concilium, quod consulatur Smo.D.N. papa, et quod Illmus. et Rmi. domini archiepiscopus et episcopus Barcinonensis cum personis eis bene visis ordinent dictam consultationem seu decretum super ea vigore 
presentis conclusionis faciendum, et quod illa seu illud in proxima congregatione legatur. Et Rdi. domini Gerundensis, llerdensis et Dertusensis episcopi ac Rdus. abbas de Villabertrando praesenti conclusioni dissenserunt et non esse locum consultationi petite vouerunt.

(Archivo General de Simancas, P.R. 27, 70 I)

Termina la copia de los decretos del concilio Tarraconense, publicados en sus dos fases.

Sumpta fuit praesens copia decretorum et dissensuum supra in octo papyri foliis presenti comprehenso scriptorum ab originali processu sacri Prouincialis Concilii Tarraconensis in quo haec et alia scripta sunt de mandato illustrissimi et reverendissimi in Christo Patris et Domini Domini Ferdinandi de Loazes, miseratione diuina sancte Tarraconensis ecclesiae archiepiscopi, sacro approbante concilio, per me Damianum Gili, apostolica et regia ac dicti reverendissimi domini Archiepiscopi auctoritatibus notarii publici Tarraconensis, dicti sacri Prouincialis Concilii scribam qui haec manu propria subscripsi, sigillique dicti concilii impressione muniui in fidem et testimonium premissorum die vicesiñă mensis octobris anno a Natiuitate Domini MDLXV.

(Archivo General de Simancas, Patronato Real, 22, 67) 